\title{
Germline and Pluripotent Stem Cells
}

\author{
Wolf Reik ${ }^{1,2}$ and M. Azim Surani ${ }^{2}$ \\ ${ }^{1}$ The Babraham Institute, Babraham Research Campus, Cambridge CB2 3EG, United Kingdom; ${ }^{2}$ Wellcome Trust Cancer \\ Research UK Gurdon Institute \& Wellcome Trust-Medical Research Council Cambridge Stem Cell Institute, University of \\ Cambridge, Cambridge CB2 1QN, United Kingdom \\ Correspondence: a.surani@gurdon.cam.ac.uk
}

\section{SUMMARY}

Epigenetic mechanisms play an essential role in the germline and imprinting cycle. Germ cells show extensive epigenetic programming in preparation for the generation of the totipotent state, which in turn leads to the establishment of pluripotent cells in blastocysts. The latter are the cells from which pluripotent embryonic stem cells are derived and maintained in culture. Following blastocyst implantation, postimplantation epiblast cells develop, which give rise to all somatic cells as well as primordial germ cells, the precursors of sperm and eggs. Pluripotent stem cells in culture can be induced to undergo differentiation into somatic cells and germ cells in culture. Understanding the natural cycles of epigenetic reprogramming that occur in the germline will allow the generation of better and more versatile stem cells for both therapeutic and research purposes.

\section{Outline}

1 The genetic and epigenetic continuum of the mammalian life cycle

2 Mechanisms regulating germ cell specification

3 From the oocyte to the early embryo
4 From pluripotent stem cells to somatic cells and back to germ cells

5 Perspective

References

Editors: C. David Allis, Marie-Laure Caparros, Thomas Jenuwein, Danny Reinberg, and Monika Lachner Additional Perspectives on Epigenetics available at www.cshperspectives.org

Copyright (C 2015 Cold Spring Harbor Laboratory Press; all rights reserved; doi: 10.1101/cshperspect.a019422

Cite this article as Cold Spring Harb Perspect Biol 2015;7:a019422 


\section{OVERVIEW}

An egg or oocyte is a most remarkable cell because it is the only cell in the body that is potentially capable of developing into a whole organism. William Harvey was the first to recognize this in 1651 when he remarked "Ex Ovo Omni" or "everything comes from an egg." He recognized that an egg probably develops progressively into an organism, and this insight was important for the concept of "epigenesis" or progressive development. This eventually led to the demise of the "preformationist" view of development, a theory proposing that individuals develop from the enlargement of tiny fully formed organisms (the so-called homunculus) contained in the germ cells. Conrad Waddington later depicted this concept in his famous illustration as an "epigenetic landscape," a symbolic representation of sequential development from an egg (Waddington 1956; a variation of which is illustrated in Takahashi 2014). Development of an entire organism from an egg is possible in some organisms without any contribution from a male, which is called "parthenogenesis," but this cannot occur in mammals because of the phenomenon of "genomic imprinting" in which fertilization of an egg by sperm is obligatory for development to adulthood.

In most organisms, development commences following fusion between sperm and eggs to generate a zygote, which gives rise not only to a new individual but, theoretically at least, to an endless series of generations. In this way, germ cells provide the enduring link between all generations. The newly fertilized egg or zygote is therefore unique because no other cell has the potential to develop into an entirely new organism. This property is referred to as "totipotency." Germ cells are unique as transmitters of both genetic and epigenetic information to subsequent generations, and they show many exceptional properties that are required to fulfill this potential. The oocyte also has the striking property of conferring totipotency on cell nuclei from somatic cells, such as a nerve cell when it is transplanted into the egg, a process referred to as cloning or nuclear reprogramming.

During development from a zygote onward, there is a progressive decline in totipotency of the newly dividing cells. In mammals, only the products of very early cell divisions retain totipotency in which each of the cells is, in principle, separately capable of generating a new organism.

Further on in development, the mammalian embryo gives rise to a blastocyst, a structure with an outer group of trophectoderm cells destined to form the placenta, and an inner group of cells that will give rise to the entire fetus and, eventually, a new organism (Gardner 1985). These inner cells will therefore differentiate into all the known 200 or so specialized somatic cells found in adults and they are, therefore, referred to as "pluripotent." Under certain culture conditions, these pluripotent cells can be "rescued" from early embryos and made to grow indefinitely in vitro while still retaining the ability to differentiate into any specific cell type found in embryos and adults, including sperm and eggs themselves (Evans and Kaufman 1981; Martin 1981). Such cells have been derived from human, mouse, and rat embryos and are called pluripotent embryonic stem (ES) cells. The capacity to generate pluripotent stem cells is lost quite rapidly when the embryo implants and commences the program of embryonic development. Our recent understanding of how pluripotency is regulated by transcription factors epigenetically has given rise to the exciting technology of "induced pluripotent (iPS) cells" by which somatic cells can be reprogrammed to iPS cells that are similar to ES cells.

Among the earliest cell types to emerge during embryonic development, after implantation, are the precursors of sperm and eggs called primordial germ cells (PGCs) (McLaren 2003). This early developmental event ensures that PGCs that eventually give rise to subsequent generations are set aside from the remaining cells that form somatic tissues. These are highly specialized cells that eventually develop into mature sperm or eggs in the adult organism, thus repeating the cycle of life, while the rest of the body's cells eventually perish. PGCs are therefore very special cells. PGCs can be isolated to derive pluripotent stem cells called embryonic germ (EG) cells.

Stem cells are also present in adults. For example, adult stem cells generate billions of different blood cells that arise from blood stem cells in the bone marrow. Similarly, our skin cells or the cells in the gut are continually replaced through differentiation of their appropriate stem cells. Adult stem cells normally only have the potential to generate cells of specific tissues and not the diverse cell types that can be made from pluripotent stem cells. One of the key research objectives is to understand the similarities and differences between pluripotent ES and adult stem cells, including the underlying epigenetic mechanisms that regulate their properties. Interestingly, our understanding of the principles behind the differentiation of adult cells has resulted in the ability to reprogram one somatic cell type into another, often termed transdifferentiation, converting, for example, skin cells into cells of the pancreas and fibroblasts into neuronal cells. Understanding the unique epigenetic properties of germ cells and pluripotent stem cells will contribute to enabling us to develop new concepts for therapies, particularly in regenerative medicine. 


\section{THE GENETIC AND EPIGENETIC CONTINUUM OF THE MAMMALIAN LIFE CYCLE}

The genetic information encoded in an individual's genome is established at fertilization and does not change during development, with the exception of mutations and some directed sequence changes occurring, for example, during VDJ gene segments recombination in the immune system (elaborated in Sec. 4 of Busslinger and Tarakhovsky 2014). Epigenetic information, on the other hand, is established in the gametes (Fig. 1A); the information stored in the chromatin template undergoes major changes during development and differentiation. DNA methylation, histone modifications, histone variants, and nonhistone chromatin proteins, as well as noncoding RNAs and higher-order chromatin structure encode this information. The key feature of epigenetic marks is that they are usually heritable from one cell generation to the next, and they can regulate gene expression. Epigenetic information is thus thought to be of critical importance for the determination and maintenance of defined and stable gene expression programs that underlie cell fate decisions during development. In totipotent and pluripotent cells, it is imagined that epigenetic marks are less stable and more plastic to allow for these cells to differentiate into any number of cell types. As development proceeds and the potency of cells becomes more and more restricted, epigenetic marks become more rigid and restrictive. Totipotent and pluripotent cells such as germ cells or ES cells (see Fig. 1B) also have the unique property of being able to reprogram the genome and erase existing epigenetic marks, a characteristic that underlies their developmental plasticity.

The interdependence of developmental decisions and epigenetic gene regulation sets up a continuum of genetic and epigenetic events in mammals. This is because developmental events that are, for example, a result of intercell signaling give rise to a specific program of gene expression that can be epigenetically fixed. Such developmental events can also set up new epigenetic events (e.g., the methylation or demethylation of imprinted genes in germ cells). In turn, the setting or erasure of epigenetic marks can determine new gene expression programs and, hence, influence the way individual cells respond to developmental cues. The resulting developmental and epigenetic continuum is particularly fascinating when it includes the germline, as this extends to the next generation and possibly beyond that into the future.

Does life therefore really begin at fertilization? It is true that, genetically, a new individual can be identified from the time of fertilization of an egg by sperm? This is when a haploid set of chromosomes from the mother comes together with a haploid set of chromosomes from the father, and the diploid genome of the offspring is formed. But, epigenetic information that will be transmitted to the offspring is also present in the gametes (Fig. 1A). For example, imprinted genes carry DNA methylation marks that differ between the male and female germ cells and these preexisting patterns are inherited by offspring (see Barlow and Bartolomei 2014). These epigenetic marks are introduced into the germ cell genomes of a parent as early as during
A

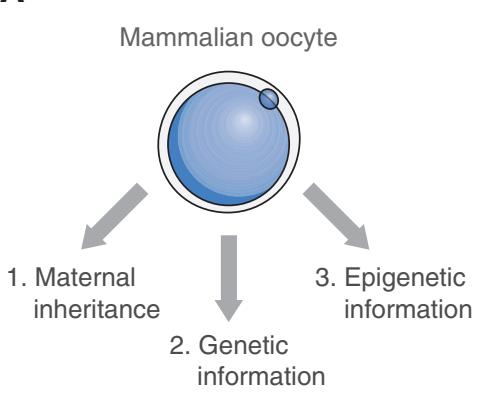

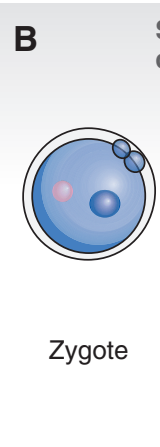

E1

\section{Stem cell} derivation

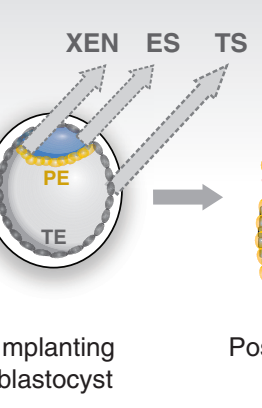

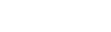$$
\text { Postir }
$$

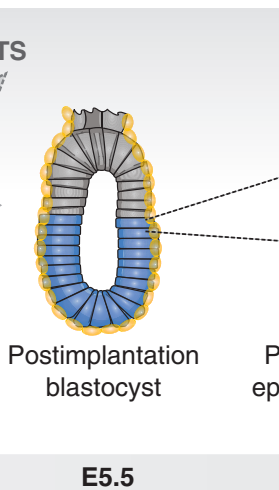

E5.5

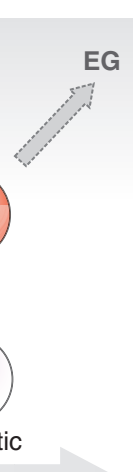

E8-13.5

Figure 1. Potential of the mammalian oocyte, zygote, and blastocyst. (A) The mammalian oocyte contains maternal RNAs and proteins (maternal inheritance), which can determine early developmental events, genetic information (maternal chromosomes), and epigenetic information (DNA methylation and chromatin marks). (B) The zygote gives rise to the blastocyst with its inner cell mass (ICM) cells (blue) giving rise to ES cells in culture. The epiblast derivative of the ICM in the postimplantation blastocyst gives rise to all somatic cells and PGCs. A range of pluripotent stem cells (top line) can be derived from the various cell types isolated from early- and late-stage blastocysts and later primitive streak embryos. Types of stem cell include XEN, extraembryonic endoderm; ES, embryonic stem; TS, trophoblast stem; EpiSC, epiblast stem cell; EG, embryonic germ. 
fetal or early postnatal development. Increasing data are showing that epigenetic marks may also occasionally be transmitted from one generation to the next resulting in transgenerational epigenetic inheritance (discussed in Sec. 2.4 of Blewitt and Whitelaw 2013).

The first lineage allocation decisions occur before implantation, during the morula to blastocyst transition, producing the inner cell mass (ICM), which gives rise to the whole of the adult organism (and pluripotent ES cells) and an outer layer of trophectoderm (TE) cells (Fig. 2). These cell-fate decisions precede specification of PGCs, which occurs after blastocyst implantation. TE cells facilitate implantation and ultimately generate the placenta, whereas the ICM cells differentiate into epiblast and primitive endoderm (PE) cells (this later blastocyst-stage implanting is illustrated in Fig. 1B).

The relative contributions of epigenetic modifications, egg cytoplasmic factors (represented as maternal inheritance in Fig. 1A), and cell-cell interactions in directing genetically driven development are being investigated. This is complementing research into elucidating the details of how different genetic programs first arise in the early embryo. We know that control of development is initially governed by maternally inherited factors. It passes to the embryo itself following the destruction of maternal factors and the activation of embryonic genome, usually at the two- to four-cell stage, when these blastomere cells acquire the totipotent state from which the ICM and TE lineages emerge. We also know that epigenetic information is carried across from the gametes to the embryo at imprinted and perhaps other genes. Other dramatic epigenetic events occur around the time of fertilization: The sperm genome (i.e., the paternal pronucleus) loses DNA methylation rapidly in the fertilized zygote, and then regains DNA and histone modifications over the subsequent cell divisions (Fig. 2). Meanwhile, the maternal genome resists zygotic DNA demethylation, but then becomes demethylated in a more protracted fashion during cleavage

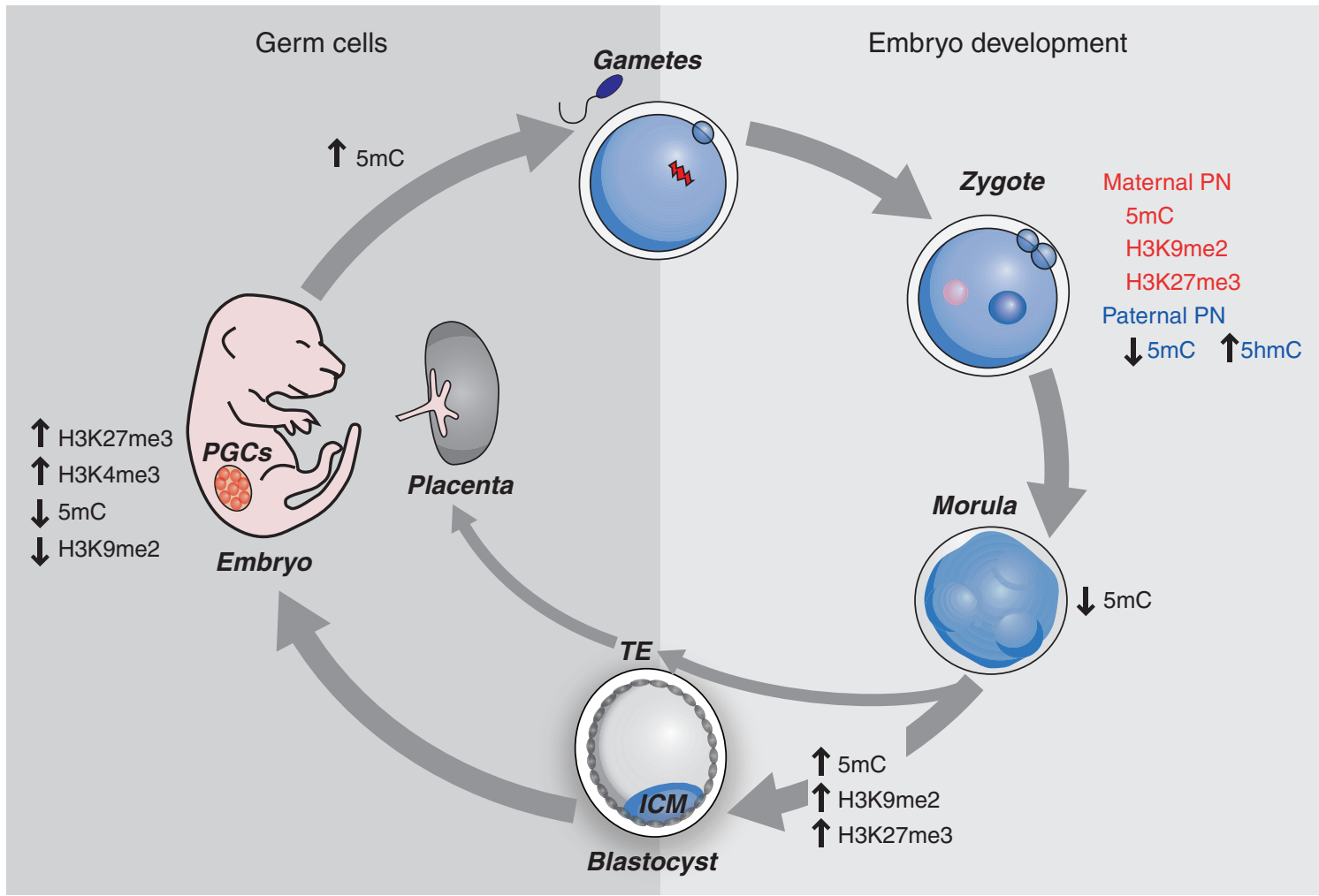

Figure 2. The epigenetic reprogramming cycle in mammalian development. Immediately after fertilization in the zygote, the paternal pronucleus (PN) is packaged with histones that lack $\mathrm{H} 3 \mathrm{~K} 9 \mathrm{me} 2$ and $\mathrm{H} 3 \mathrm{~K} 27 \mathrm{me} 3$, whereas the maternal chromatin contains these marks. The paternal $\mathrm{PN}$ also rapidly loses 5 -methylcytosine $(5 \mathrm{mC})$ on a genomewide scale, whereas the maternal does not. Passive loss of $5 \mathrm{mC}$ occurs during preimplantation development until the blastocyst stage when the ICM cells begin to acquire high levels of $5 \mathrm{mC}, \mathrm{H} 3 \mathrm{~K} 9 \mathrm{me} 2$, and $\mathrm{H} 3 \mathrm{~K} 27 \mathrm{me}$. The placenta, which is largely derived from the TE of the blastocyst, remains relatively hypomethylated. PGCs undergo demethylation of $5 \mathrm{mC}$ and $\mathrm{H} 3 \mathrm{~K} 9 \mathrm{me} 2$ progressively as they migrate into the gonads. De novo DNA methylation, including parent-specific imprinting, takes place during gametogenesis. 
divisions of the early embryo discussed later in Section 3.2 (illustrated in Fig. 3 of Li and Zhang 2014). These reprogramming events may be important to achieve totipotency of the zygote and pluripotency of ICM cells. Yet, these somewhat opposing and distinct epigenetic programs lead to an overall loss of gametic epigenetic information, and it is likely that these dynamic reprogramming events interact with the cellular and genetic processes that determine the earliest processes of cell allocation into ICM and TE lineages.

Epigenetic regulation at the later blastocyst stage differs considerably between the extraembryonic (TE) and embryonic lineages (ICM). For example, the overall levels of DNA methylation are lower in the extraembryonic tissues, and maintenance of imprinting and imprinted $\mathrm{X}$ inactivation can be different. Ultimately, however, ICM and TE cells, like the later differentiated PGCs, are largely determined by a genetic program involving transcription factors and, where appropriate, pluripotency genes. Yet, some of these transcription factor genes appear to be epigenetically regulated, which then contributes to the maintenance of cell-fate decisions.

After implantation of blastocysts, the postimplantation epiblast cells start to undergo modifications of DNA and chromatin. These are the cells that give rise to both germ cells and those that will differentiate into diverse cell types of the body. The earliest signs for the onset of germ cell fate are seen among a small group of cells formed in the early postimplantation embryo at E6.25, in response to receiving signaling molecules that come from other parts of the conceptus, primarily the adjacent extraembryonic lineages, which include the cells destined to form the placenta. Germ cell specification entails repression of somatic cell gene products while they begin to show expression of the unique germ-cell-specific genes. This genetically governed function is also responsible for initiating epigenetic reprogramming in early germ cells, leading to the erasure and reestablishment of imprinting, chromosome recombination during meiosis, and reduction divisions to form haploid gametes. These various stages of early development thus far described clearly illustrate that the epigenetic modifications occur progressively and accompany changes in genetic programs.

\section{MECHANISMS REGULATING GERM CELL SPECIFICATION}

The specification of germ cells in animals is one of the earliest events during development, segregating them from somatic cells (Surani et al. 2004). Germ cells eventually generate the totipotent state. This section focuses on the processes of mouse-germline specification and their subse- quent maturation as they migrate into the developing gonads.

The events and mechanisms known to direct the process of germline specification in mice occur in postimplantation epiblast cells that emerge from ICM cells after the blastocyst (which contains just three cell types: ICM, TE, and PE) has implanted. PGCs after specification migrate into the developing gonads and come to reside in their final destination, the male or female gonads (illustrated schematically on the left side of Fig. 2). A description of the events and mechanisms regulating early embryogenesis, from early cleavage and morula stages through to the early blastocyst, are detailed in Section 3 (corresponding to stages of the life cycle shown on the right side of Fig. 2).

\subsection{Principles of Germline Development in Different Animal Groups}

There are two key modes by which a germ cell lineage can be established; these are referred to as the preformation mode (this is distinct from the old usage of the word as in preformationism) and the epigenesis mode (Extavour and Akam 2003). The first involves the maternal inheritance of preformed germ cell determinants by specific cells, as occurs in Caenorhabditis elegans and Drosophila melanogaster (Fig. 3) (Leatherman and Jongens 2003; Blackwell 2004). In contrast, the epigenesis mode of germ cell specification is a process in which a group of potentially equivalent pluripotent cells acquire a germ cell fate in response to inductive signals, whereas the remaining cells acquire the somatic fate (Lawson and Hage 1994; McLaren 2003). This mechanism for germ cell specification operates in mice and probably in other mammals, but also in some other vertebrates such as Axolotls.

\subsection{Early Germline Development in Mammals}

PGCs in mice are first detected at E7.5 (the early bud stage), as a cluster of approximately 30 to 40 cells that constitute the founder population of the germ cell lineage (Lawson and Hage 1994; McLaren 2003). They are positive for alkaline phosphatases and located within the extraembryonic mesoderm at the base of the allantois (see Fig. 4). Clonal analysis reveals that the proximal epiblast cells located adjacent to the extraembryonic ectoderm at E6.0-E6.5 (prestreak and early-streak-stage embryos) give rise to both PGCs and tissues of the extraembryonic mesoderm (Lawson and Hage 1994). Before PGC specification, however, the epiblast cells acquire a state of competence in response to signals that include Wnt signaling (Ohinata et al. 2009). Consequently, proximal epiblast cells form PGCs in response to signaling molecules produced by sur- 


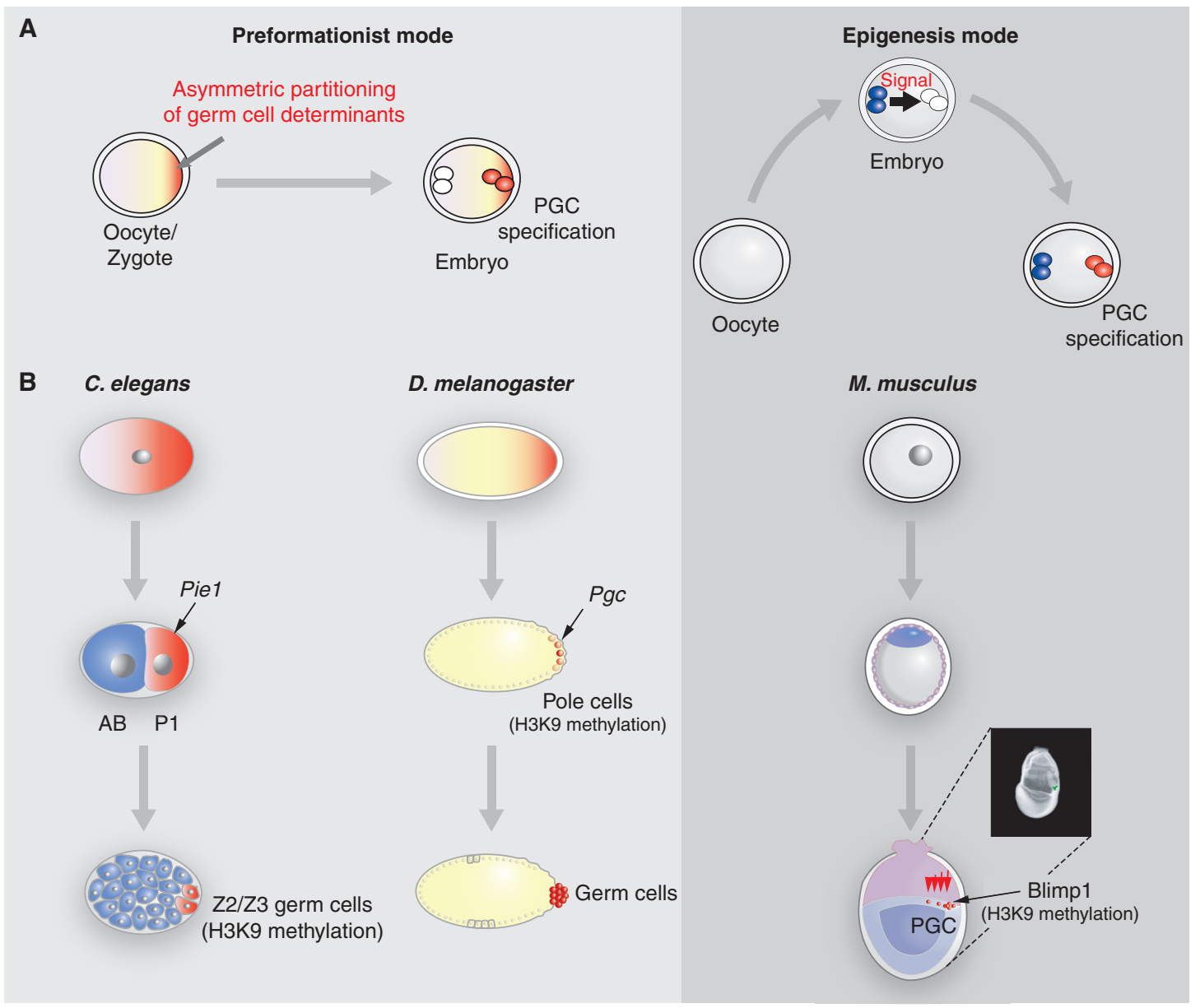

Figure 3. Early germ cell determination in the mouse. (A) Two models summarize the mode by which germ cells are determined in various organisms. The preformationist mode assumes one or more localized determinants in the oocyte or early embryo specify progeny cells becoming PGCs. In the epigenesis mode, a signal emanating from a neighboring cell(s) in the early embryo determines the future PGCs. (B) This part of the figure highlights the features that contribute to the repression of somatic gene programs during germline specification in various organisms. In Caenorhabditis elegans, the germline lineage (red) is specified after the first division of the zygote by expression of Pie1, which confers transcriptional quiescence. The other cell (blue) gives rise to somatic tissues. In Drosophila melanogaster, the precursors of the germ cells are the so-called pole cells contained on one side of the zygote syncytium (i.e., multinucleated); transcriptional quiescence in these cells depends on localized RNA from the gene $P g c$ and high levels of H3K9 methylation. In Mus musculus, the earliest precursors of the germ cells are visible by expression of Blimp1 at the base of the allantois. Blimp1 initiates transcriptional quiescence in these cells.

rounding extraembryonic ectoderm and primary endoderm. Among the most important signals for PGC specification itself are Bmp8b and Bmp4, which are expressed most strongly from the posterior extraembryonic ectoderm, contributing to PGC specification (Fig. 4) (Lawson et al. 1999).

To gain detailed insights into the genetic program of PGC specification, single-cell copy DNAs were generated from the founder PGCs and their neighboring somatic cells (Saitou et al. 2002). A variety of markers were used to distinguish between PGCs and somatic cells. This screen initially identified fragilis, a novel member of the interferon- inducible transmembrane protein family implicated in cell aggregation, and stella (also known as PGC7), a nucleocytoplasmic protein. Further investigations showed that fragilis is expressed in the proximal epiblast cells at E6.0 (Fig. 4) when they gain competence to give rise to both PGCs and the neighboring extraembryonic mesoderm cells. The fragilis-positive cells move to the posterior proximal region during gastrulation, although the precise role of fragilis at this time is unknown. The founder population of PGCs is subsequently detected among this fragilis-positive population of cells by expression of stella. At the same time, founder PGCs show expression of pluripotency genes 
E5.5
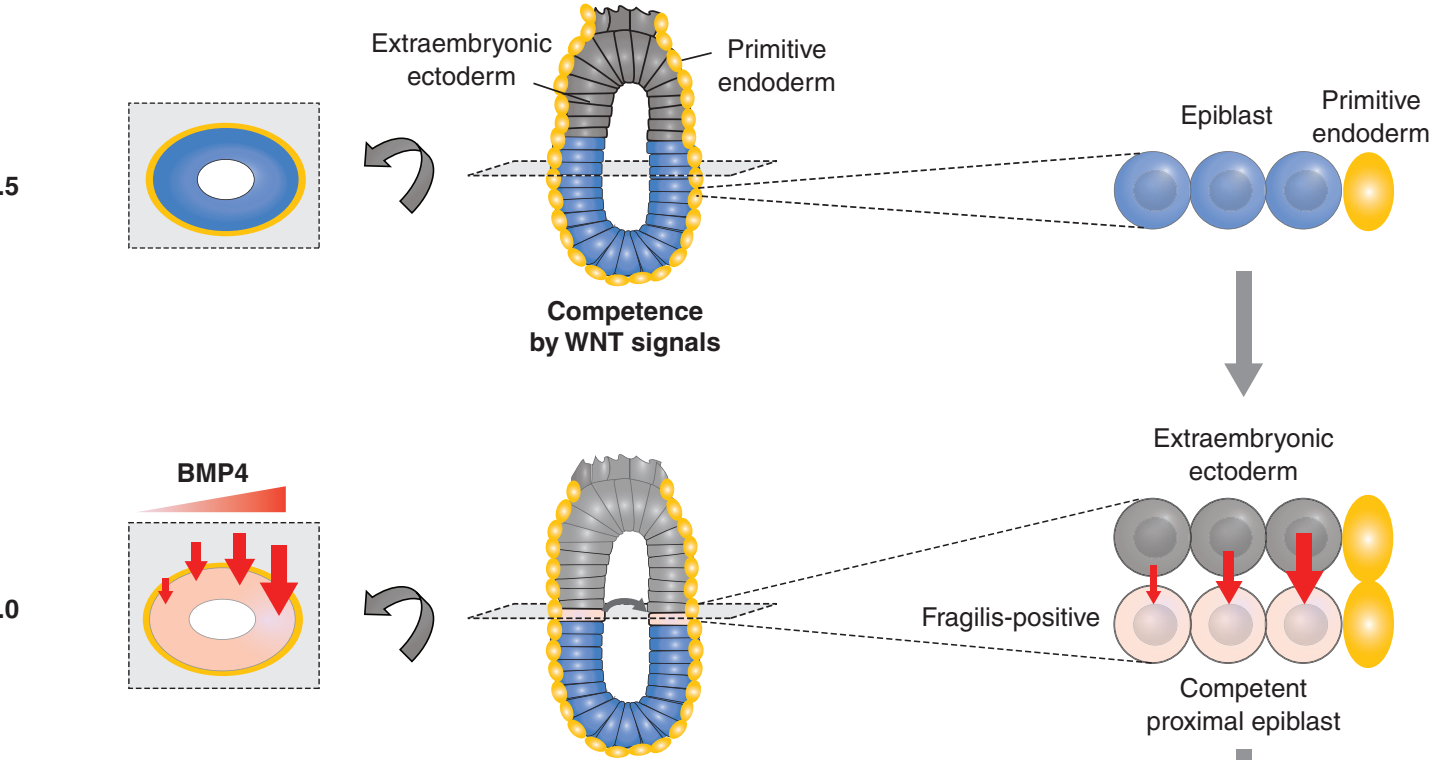

Extraembryonic

E6.0
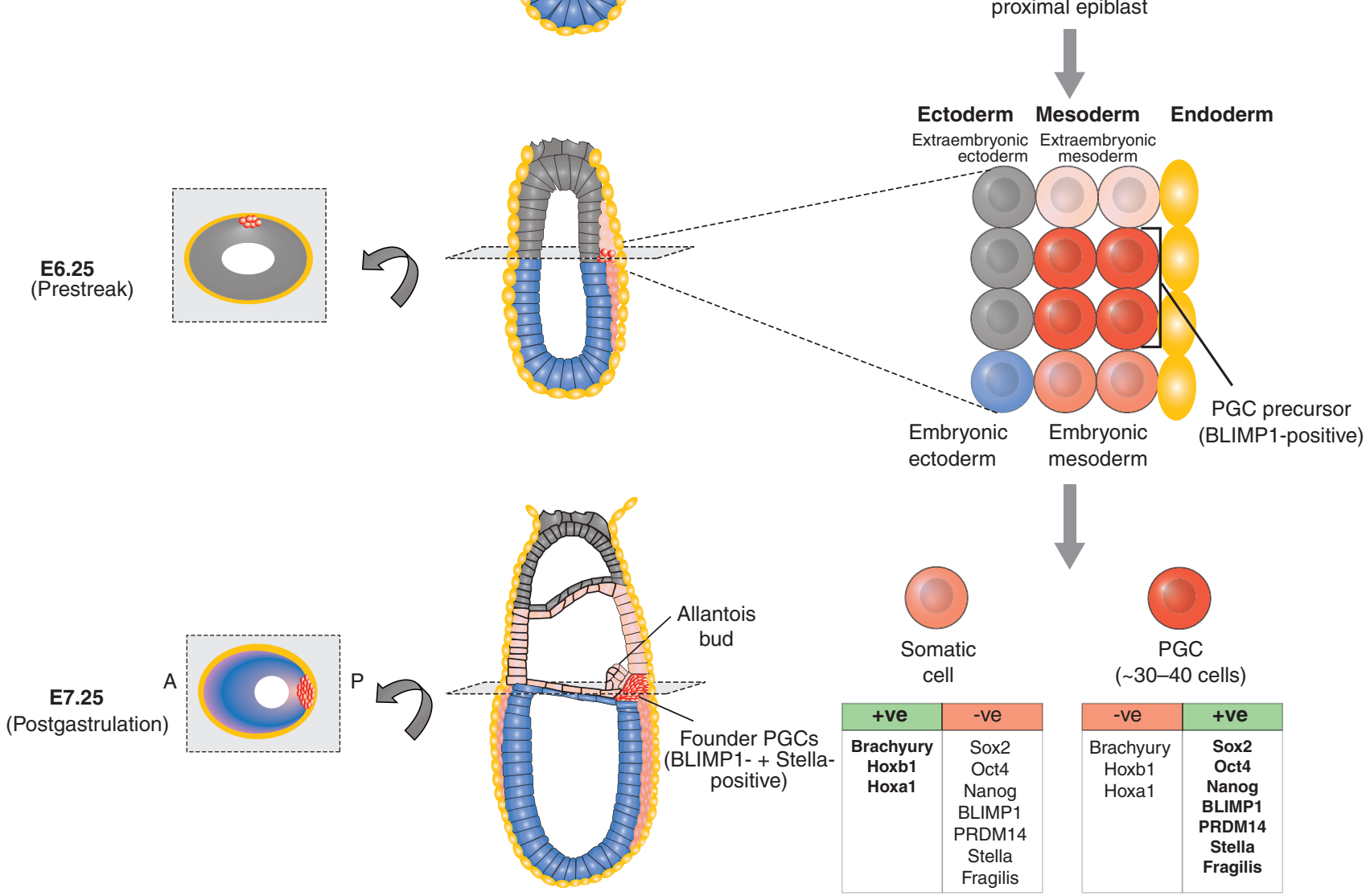

Figure 4. Germline development in mice. Postimplantation proximal competent epiblast cells at E6 (pink) respond to BMP4 signal from the extraembryonic tissues ( pink), which activates BLIMP1. Expression of BLIMP1 marks the onset of commitment to the primordial germ cell fate (red), whereas other cells become somatic cells. 
including Sox2, Oct4, and Nanog (see Sec. 4.2 for a more detailed description), suggesting that PGCs reacquire an underlying pluripotency, which is lost in the neighboring somatic cells (Fig. 4). In contrast, the founder PGCs show repression of some genes including Brachyury, Hoxb1, and Hoxa1, which are, at this time, significantly up-regulated in somatic neighbors. The repression of Hox genes among others is part of an important mechanism that underlies repression of the somatic cell fate in founder PGCs (elaborated in Sec. 2.4; Saitou et al. 2002).

Based on the analysis of the emergence of founder PGCs, it is evident that, as in other organisms, repression of the somatic program is likely to be a key feature of PGC specification in mice (Seydoux and Strome 1999; Blackwell 2004; Surani et al. 2004). The lysine (K) methyltransferase (KMT) class of histone-modifying enzymes or "writers" (for more detail, see Allis et al. 2014; Cheng 2014) were analyzed for differential expression between PGCs and neighboring somatic cells. KMTs modify histone lysine residues through the addition of one to three methyl groups. Methylation of histones $\mathrm{H} 3$ and $\mathrm{H} 4$ at positions $\mathrm{H} 3 \mathrm{~K} 9$ and $\mathrm{H} 4 \mathrm{~K} 20$ is generally associated with repressive chromatin regions. Methylation at $\mathrm{H} 3 \mathrm{~K} 4$ and $\mathrm{H} 3 \mathrm{~K} 36$, however, generally correlates with active transcription. Some of the KMT genes, such as G9a, Pfm1, Set1, and Ezh2, were detected both in the founder PGCs and the somatic cells. However, one of these genes, Blimp1 (B lymphocyte maturation-induced protein-1 or prdm1), showed expression exclusively in the founder PGCs and not in the neighboring somatic cells at E7.5 (Ohinata et al. 2005). Blimp1 is a known transcriptional repressor with a SET/PR domain (a domain that typically acts as a methyltransferase), a proline-rich region that can recruit Groucho and $\mathrm{HDAC} 2$, five $\mathrm{C} 2 \mathrm{H} 2$ zinc fingers that can form a complex with Prmt5, and an acidic tail (Gyory et al. 2004; Sciammas and Davis 2004, Ancelin et al. 2006). Blimp1 was first identified for its role during specification of plasma cells following repression of the B-cell program in the precursor cells (Turner et al. 1994). Blimp1 is indeed widely expressed during mouse development.

Detailed analysis of Blimp1 in early mouse embryos led to some unexpected findings. Among them was the discovery that Blimp1 expression commences in the proximal epiblast cells at E6.25 at the onset of gastrulation, initially in only four to six cells that are in direct contact with the extraembryonic ectoderm cells (Fig. 4) (Ohinata et al. 2005, 2009). Blimp1 expression is detected at one end of the short anterior-posterior axis in a region that is destined to form the posterior proximal region. The number of Blimp1-positive cells increase progressively so that there are approximately 20 cells at the midstreak stage that are seen to form a tight cluster in the posterior proximal region at E6.75. At the E7.5 early bud stage, the number of Blimp1-positive cells increases to approximately 40 . These cells constitute the founder population of PGCs, and show expression of the classical alkaline phosphatase PGC marker and commence expression of stella (Fig. 4). A genetic lineage tracing experiment confirmed that all the Blimp1-positive cells originating in the epiblast from E6.25 onward are indeed lineage restricted PGC precursor cells. These data contrast with the previous hypothesis, based on clonal analysis, which suggested that the proximal epiblast cells at E6.0E6.5 are not lineage restricted to give rise exclusively to PGCs because clonal descendants of individual cells could give rise to both a somatic and germ cell (Lawson and Hage 1994; McLaren and Lawson 2005). A likely explanation for this discrepancy may be that in the clonal analysis, the marked cells may initially have been negative for Blimp1 and they subsequently divided to generate a positive cell that gave rise to PGCs, whereas the daughter cell produced a somatic descendant. The mechanism that regulates the accretion of Blimp1-positive cells is currently unknown.

\subsection{The Role of Blimp1 in Specification of PGCs}

Analysis of the role of Blimp1 in PGC specification has generated insights into the underlying mechanism of germ cell specification in mice. Loss of function of Blimp1 showed that this is a key determinant of PGC specification in mice (Ohinata et al. 2005; Vincent et al. 2005). At E7.5, Blimp1 mutant embryos contain an aberrant cluster of approximately 20 PGC-like cells, unlike control embryos in which the PGCs continue to proliferate and commence migration out of the cluster. Furthermore, the number of aberrant PGC-like cells fails to increase when examined at E8.5 (Ohinata et al. 2005).

Single-cell analysis of mutant PGC cells revealed a lack of consistent repression of Hox genes. Therefore, it is likely that Blimp1 has a role in the repression of the somatic program in founder PGCs. There was also inconsistency in the up-regulation of PGC-specific genes such as stella and Nanos3, and some pluripotency-specific genes such as Sox 2 in mutants. These findings stress that Blimp1 has a critical role as a transcriptional regulator during PGC specification and in the prevention of these cells from acquiring a somatic cell fate.

Studies on B cells have revealed that Blimp1 is necessary to induce differentiation into plasma cells through repression of key molecules that maintain B-cell identity (see Sec. 3.2 of Busslinger and Tarakhovsky 2014 for details; Turner et al. 1994; Sciammas and Davis 2004). It does this through the formation of a Groucho and HDAC2 repressor complex (Ren et al. 1999). Its zinc fingers also seem important for the formation of a complex with G9a (Gyory et al. 2004), a histone KMT that is required for H3K9me2. Blimp1, 
which itself contains a SET/PR domain that typically acts as a methyltransferase, has no known KMT activity, and how it functions during PGC specification is unknown.

Blimp1 is an evolutionarily conserved gene in both vertebrates and invertebrates and it has a variety of functions. For example, it has a role in the development of several lineages in vertebrates such as the zebrafish and Xenopus (de Souza et al. 1999; Roy and Ng 2004; Hernandez-Lagunas et al. 2005), although not specifically in germ cell specification. This implies that the gene has acquired a new role in PGC specification in mice and perhaps in all mammals. For this highly conserved gene, it suggests that additional control elements must have evolved to drive its expression in PGC precursors and founder cells.

Analysis and comparison of Blimp1 mutant versus control PGC cells led to the discovery of a second key regulator of PGC specification called Prdm14, which like Blimp1 is another PR/SET domain family member (Yamaji et al. 2008). Blimp1, together with Prdm14, is involved in the repression of the somatic program and onset of epigenetic reprogramming in PGCs, leading to global DNA demethylation described in Section 2.5.

\subsection{Repression of the Somatic Program in Germ Cells: An Evolutionarily Conserved Phenomenon}

The mechanism of germ cell specification is not evolutionarily conserved, which is evident when comparing the mechanism in mice with the events in two other well-studied model organisms, D. melanogaster and C. elegans, as discussed previously in Section 2.1 (Seydoux and Strome 1999). The differences in the mechanism of germ cell specification are primarily accounted for by the differences in the mode of early development in these different organisms. The additional complexities imposed by the phenomenon of genomic imprinting in mammals contribute to these differences. Importantly, however, the repression of the somatic gene expression program during the specification of germ cells is a shared phenomenon in diverse organisms although the molecular mechanisms may differ (Seydoux and Strome 1999; Leatherman and Jongens 2003; Saitou et al. 2003; Blackwell 2004).

In C. elegans, the first cell division of the zygote is asymmetric: it establishes a somatic cell (AB), whereas the second cell (P1) is set aside to establish the germ cell lineage (Fig. 3B). Indeed, each of the P1, P2, and P3 cells produce a somatic cell when they divide, and the latter commence transcription and differentiation. The $\mathrm{P} 1-\mathrm{P} 3$ cells destined for the germ cell lineage remain transcriptionally quiescent. Transcriptional quiescence is maintained by a zinc finger protein called PIE-1. This protein competes with the carboxy-terminal domain (CTD) of RNA polymerase II (Pol
II) for the phosphorylating protein CDK9. When CDK9 is not available to phosphorylate Ser- 2 of the RNA Pol II CTD, RNA Pol II cannot transition into the active holoenzyme necessary for transcriptional elongation (for more detail, see Seydoux and Strome 1999; Zhang et al. 2003; Allis et al. 2014). However, both the somatic and germ cell blastomeres show transcriptionally permissive chromatin states as seen by high levels of genome-wide $\mathrm{H} 3 \mathrm{~K} 4$ methylation. Later, when the $\mathrm{P} 4$ blastomere divides to form two germline cells, Z2 and Z3, a repressive chromatin state becomes evident, with loss of $\mathrm{H} 3 \mathrm{~K} 4$ methylation and acquisition of high levels of repressive H3K9 methylation (Schaner et al. 2003). Thus, during the establishment of the germ cell lineage in C. elegans, despite transcriptional quiescence, the chromatin starts off in a transcriptionally permissive state and changes to an inactive state.

The establishment of the germ cell lineage in D. melanogaster is again distinct from what is observed in the mouse and worm. The germline precursors, called the pole cells, are detected before the onset of embryonic development in the fertilized syncytial (multinucleated) egg (Fig. 3B), and these are again transcriptionally quiescent because of a lack of RNA Pol II CTD phosphorylation, as observed in C. elegans (Seydoux and Dunn 1997; Van Doren et al. 1998; Schaner et al. 2003). Although this transcriptional silencing is also associated with the repressive chromatin modification $\mathrm{H} 3 \mathrm{~K} 9$ me, pole cells are destined to form only germ cells. These cells are thus equivalent to the $\mathrm{Z} 2$ and Z3 cells that divide from the parent P4 cell in C. elegans that are destined for the germ cell lineage only. Furthermore, regulation of transcriptional silencing in pole cells is dependent on the polar granule component ( $p g c)$ gene because loss of $p g c$ causes a loss of gene repression although the pole cells are still detected. The mutant pole cells show RNA Pol II CTD phosphorylation of Ser 2, indicative of a transcriptionally active elongating RNA Pol II complex (Deshpande et al. 2004; Martinho et al. 2004). This has led to the suggestion that $p g c$ might sequester critical components needed for the phosphorylation of RNA Pol II CTD at Ser 2, preventing the transition of RNA Pol II from the preinitiation complex to an active elongation complex.

As discussed in Section 2.3, Blimp1 not only is a key marker of PGCs, but is key in repressing somatic gene programs. The analysis of specification of germ cells during development in mice, flies, and worms clearly illustrates the fact that transcriptional repression that is presumably essential to repress the somatic cell fate is found in all three organisms, although the precise mechanisms by which this is achieved differ markedly. This is evidently because of the differences in events associated with early development of the different species. 


\subsection{Regulation of Epigenetic Programming after PGC Specification in Mice}

Extensive epigenetic programming and reprogramming occurs in the germ cell lineage following the specification of PGCs (Hajkova et al. 2002; Lee et al. 2002; Seki et al. 2005, 2007; Hajkova et al. 2008, 2010; Popp et al. 2010; Guibert et al. 2012; Hackett et al. 2012, 2013; Kobayashi et al. 2012; Seisenberger et al. 2012; Vincent et al. 2013; Yamaguchi et al. 2013). This period of development is marked by the erasure of some of the repressive epigenetic modifications (Fig. 2), allowing the germ cell lineage to acquire an underlying pluripotent characteristic, which may be a prerequisite for subsequent totipotency.

Among the key changes observed is the erasure of the repressive histone $\mathrm{H} 3 \mathrm{~K} 9 \mathrm{me} 2$ mark at E8.0, together with a decrease in the levels of HP1 $\alpha$ within the euchromatic and pericentric heterochromatic regions by E9.0 (Seki et al. 2005). At the same time, there is also a decline in the overall levels of DNA methylation in PGCs from E8.0 onward.
Simultaneous to the decline in H3K9me2 and DNA methylation is the progressive increase in $\mathrm{H} 3 \mathrm{~K} 27 \mathrm{me} 3$, a repressive modification mediated by the polycomb group protein, Ezh2 (Fig. 5). The loss of DNA methylation is due to the repression of de novo DNA methyltransferases Dnmt3a and Dnmt3b, and a decline in the Np95 protein (also called UHRF1) that targets Dnmt1 (the maintenance DNA methyltransferase) to the replication fork (discussed in Kurimoto et al. 2008; Seisenberger et al. 2012; Kagiwada et al. 2013; Cheng 2014). It is noteworthy that the loss of H3K9me2 and DNA methylation also coincides with the reexpression of a key pluripotency-associated gene, Nanog (Yamaguchi et al. 2005). Nanog is first expressed in the inner cells of the late morula and ICM cells of blastocysts. However, expression of this gene is down-regulated after implantation, and the gene is only the reexpressed in PGCs and not in the neighboring somatic cells. The collective expression of pluripotency genes including Nanog, Oct4, Sox2, and Esg1 shows that germ cells acquire characteristics of pluripotency (Fig. 5). One factor that is apparently important

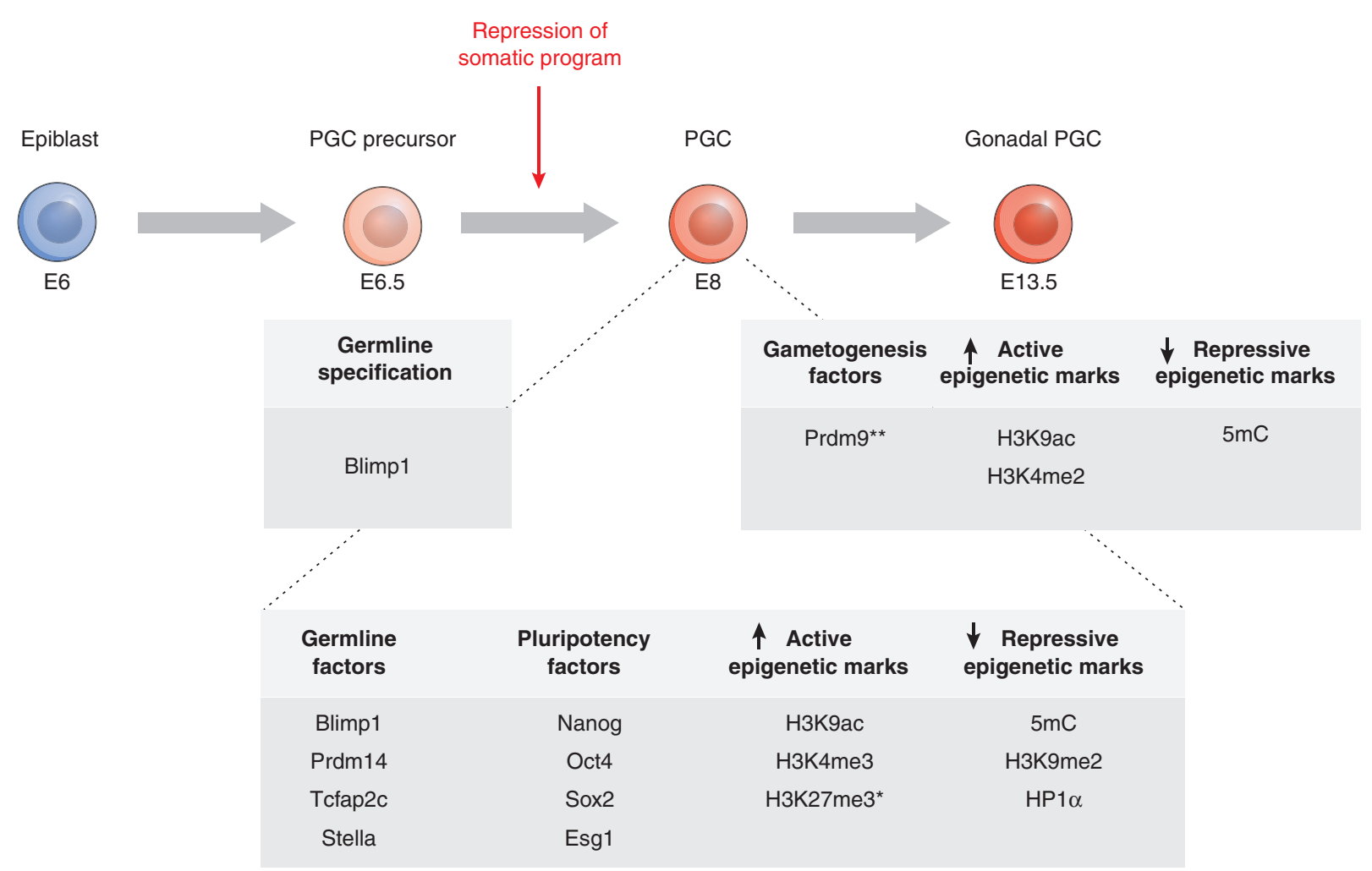

Figure 5. Early epigenetic events during germ cell specification. Expression of Blimp1, Prdm14, and Tcfap2c in descendants of epiblast cells leads to repression of the somatic gene expression program and initiation of the germ cell program (red). This is followed by expression of Stella, Nanog, and Esg1, increase in the H3K4me3 and H3K9ac active marks, as well as the repressive H3K27me3 mark $\left(^{*}\right)$, and loss of $\mathrm{H} 3 \mathrm{~K} 9 \mathrm{me} 2$ and $5 \mathrm{mC}$. The PGCs start to show loss of DNA methylation as they migrate to the developing gonads, with comprehensive loss of DNA methylation and the erasure of imprints occurring shortly after they enter the gonads. PRDM9 is crucial in the later process of gametogenesis, marking the transition from PGCs to gametes. This occurs with the onset of meiosis at E13.5 in females. ${ }^{* *}$ In males gametogenesis occurs postnatally. 
for expression of pluripotency genes in early PGCs is the H3K27me3 demethylase, Utx, likely counteracting the repressive effects of the overall increase in H3K27me3 (Mansour et al. 2012). The expression of the pluripotency network in PGCs is extensive and comparable to ES cells (Seisenberger et al. 2012).

Additional extensive epigenetic programming events ensue when PGCs enter into the developing gonads (Surani et al. 2004). First, there are increases in H3K4me2 methylation and $\mathrm{H} 3 \mathrm{~K} 9$ acetylation, which are characteristic of permissive chromatin states, excluding H3K9 methylation. In addition, there is very extensive genome-wide DNA demethylation (Fig. 5) that includes the erasure of parental imprints and methylation in single-copy genes. In female embryos, the inactive $\mathrm{X}$ chromosome is also reactivated at this time. Genome-wide demethylation is likely to occur by a combination of active and passive mechanisms, including down-regulation of $\mathrm{Np} 95$ (discussed in Kurimoto et al. 2008; Cheng 2014), the activation-induced deaminase (AID) and thymine-DNA glycosylase (Popp et al. 2010; Cortellino et al. 2011), and TET1 and TET2, which are potentially coupled to the base excision repair pathway (see Fig. 6 of Li and Zhang 2014 and Feng et al. 2010; Hajkova et al. 2010; Hackett et al. 2012; Saitou et al. 2012; Dawlaty et al. 2013; Hackett and Surani 2013; Vincent et al. 2013; Yamaguchi et al. 2013).

Not all epigenetic marks are completely removed during germ cell development, despite effective mechanisms operating to erase "acquired" epigenetic modifications. For example, DNA methylation of the intracisternal A particle (IAP) retrotransposon family and some 200 or so other genomic locations is only partially reprogrammed (Lane et al. 2003; Popp et al. 2010; Guibert et al. 2012; Seisenberger et al. 2012; Hackett and Surani 2013). When some epigenetic marks are incompletely removed during gametogenesis, this can apparently lead to epigenetic inheritance through the germline, of which there are a number of examples now in mammals (e.g., see Fig. 6 in Blewitt and Whitelaw 2013 and Chong and Whitelaw 2004), and this could potentially explain the transgenerational epigenetic inheritance of some metabolic phenotypes (FergusonSmith and Patti 2011). How widespread this phenomenon is and how many gene loci it involves needs to be established.

\subsection{The Germline and Stem Cells: A Reversible Phenotype}

Pluripotent stem cells can be derived from ICM and germ cells (Fig. 1B). More specifically, pluripotent EG cells can be made from PGCs when cultured in the presence of FGF2 (Matsui et al. 1992; Resnick et al. 1992). They are, in many respects, similar to pluripotent ES cells (discussed more extensively in Sec. 4) except that EG cells may show erasure of parental imprints during their derivation (Tada et al. 1998; Leitch et al. 2010). Recent studies have shown that EG cells can also be derived from rat PGCs (Leitch et al. 2010).

As PGCs show some characteristics of pluripotency while retaining unipotency in that they are only able to form sperm or eggs, it is probable that mechanisms exist to allow PGCs to retain their distinct lineage-specific characteristics. How this is achieved is as yet unclear, but it is possible that Blimp1 may have a continuing role following the initial specification of PGCs. During the derivation of EG cells, it is assumed that unipotent restriction is relieved and they acquire an overtly pluripotent character with the ability to differentiate into many distinct cell types, which seldom occurs with germ cells in vivo. It is noteworthy that the derivation of EG cells becomes progressively less efficient, however, when later-stage PGCs from E11.5 and E12.5 are used. This further suggests a change in the characteristics of these cells from E11.5 when they begin their differentiation pathway toward definitive male and female germ cells.

\subsubsection{Development of Germ Cells from Pluripotent ES Cells}

A characteristic of pluripotent stem cells is their ability to differentiate into all types of somatic tissues when introduced into blastocysts, including germ cells (Fig. 6) Increasing efforts are being made to generate different tissues more efficiently from ES cells in culture. It is now possible to generate PGCs, and possibly sperm- and egglike structures from ES cells in culture (Hubner et al. 2003; Toyooka et al. 2003; Geijsen et al. 2004; Hayashi et al. 2011;

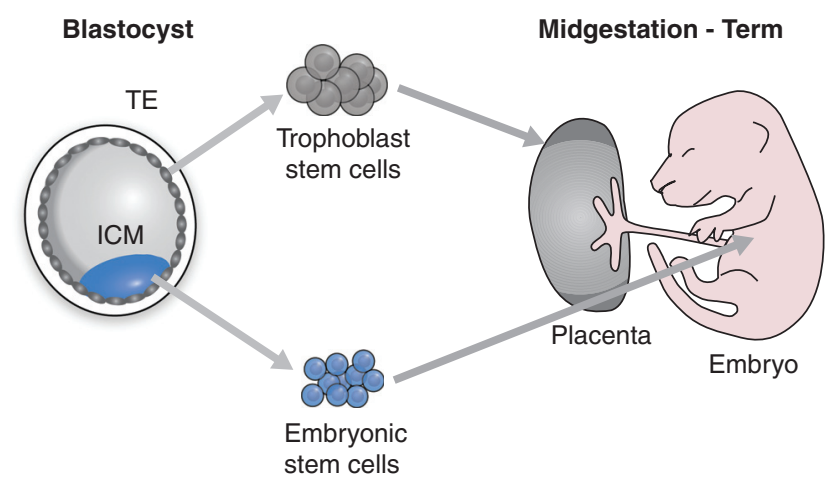

Figure 6. Differentiation of ES cells into different cell types in vitro. ES cells can be differentiated in vitro under suitable culture conditions into many different cell types such as neurons, muscle cells, and even germ cells (oocytes). 
Vincent et al. 2011). This has opened up the possibility of studying the process of germ cell specification in vitro, with the hope of being able to determine the precise mechanisms involved, aided by an ever-increasing knowledge base of the genetic programs that govern PGC and gamete cell function. The ability to in vitro differentiate PGCs from ES cells may also provide a model system to examine the regulation of epigenetic reprogramming in this lineage. Such an approach could ultimately advance our understanding of the human germ cell lineage, which, for ethical reasons, has been hard to research to date. Furthermore, if it becomes possible to direct differentiation toward human oocytes from cultured ES cells, it may be possible to use them for "therapeutic" cloning, circumventing the need for donor oocytes that are difficult to obtain. These oocytes could then be used for somatic nuclear transplantation to generate blastocysts, and subsequently to derive ES cells from. This is because somatic nuclei undergo reprogramming to totipotency when transplanted into oocytes (elaborated in Hochedlinger and Jaenisch 2014). This procedure is likely to complement the currently used direct derivation of iPS cells from somatic tissues.

The use of human embryos and ES cells in research and therapy does raise many ethical issues. A variety of guidelines and regulations exist in different countries to monitor research in this area. Within these ethical frameworks, it is hoped that the generation of viable gametes from ES cells, if possible, may lead to advances in reproductive medicine.

\subsection{From PGCs to Gametes}

The next stage in the development of the germ cell lineage is the initiation of gametogenesis and entry of germ cells into meiosis. The gonadal somatic environment regulates the timing of this event. In females, germ cells arrest in meiotic prophase whereas male germ cells enter into mitotic arrest. A number of environmental signals dictate whether germ cells enter meiosis or not. Recently, a novel gene, Prdm9 (also called Meisetz), another PR/SET domain family member, was identified and shown to play a crucial role in initiating meiosis (Hayashi et al. 2005). The PR/SET domain has proven $\mathrm{H} 3 \mathrm{~K} 4 \mathrm{me} 3$ catalytic activity and also possesses multiple zinc-fingers. Expression of $\operatorname{Prdm} 9$ is specific to germ cells, and is detected at the time of entry into meiotic prophase in females at E13.5 and in postnatal testis. It is likely that Prdm9/PRDM9 in mouse and human germ cells may introduce epigenetic marks or "hot spots" that constitute narrow segments of the genome as sites for meiotic recombination. Mutation in $\operatorname{Prdm} 9$ results in sterility in both males and females, demonstrating its essential role in germ cells. The mutant germ cells show marked deficiency in the DNA double-strand break repair pathway and pairing of homologous chromosomes during meiosis. These studies suggest a significant role for epigenetic mechanisms in germ cells during meiosis (Baudat et al. 2010; Parvanov et al. 2010).

Extensive chromatin modifications continue during spermatogenesis. Eventually, the somatic linker histones are replaced by testis-specific variants (Kimmins and Sassone-Corsi 2005), followed by the replacement of most histones with protamines. Studies have shown that Suv39, an $\mathrm{H} 3 \mathrm{~K} 9$ histone methyltransferase, is involved in gene repression and chromosome pairing. Two such SET-domain proteins, Suv39h1 and Suv39h2, have roles in male germ cells, the latter being expressed preferentially in the testis, and accumulating in the chromatin of the sex vesicle (i.e., XY chromosome pair). Mutations in both Suv39h1 and Suv39h2 result in infertility because of the arrest of spermatogenic cells (Peters et al. 2001). In addition, there is also a chromatoid body; this is a cloud-like cytoplasmic structure present in male germ cells. It is an RNA-processing body consisting of Dicer and Argonaute proteins and microRNAs, a germ-cell-specific cytoplasmic organelle that interacts with the nucleus and contains compacted messenger RNA.

Noncoding RNAs, the RNA interference (RNAi) machinery, and histone lysine methyltransferases are implicated in the process of germ cell renewal during spermatogenesis. The members of the Piwi/Argonaute (called Miwi in mice) family have been reported to play a role in RNAi pheomena. Loss of Miwi-like proteins (Mili) results in sterility in males (Kuramochi-Miyagawa et al. 2004), causing elevated expression of retrotransposon transcripts, IAP, and Line 1. The involvement of Miwi-like proteins in their repression has been directly demonstrated shown through the piRNA pathway (Siomi et al. 2011).

Interestingly, pluripotent stem cells from spermatogonial stem cells can even be recovered from adult mouse testis (Kanatsu-Shinohara et al. 2004; Guan et al. 2006). These cells may be maintained in culture indefinitely, but unlike ES cells, they have a paternal (androgenetic) imprint. Nonetheless, they can differentiate into a variety of somatic cell types in vitro and in vivo, and can contribute to the germline in vivo. These cells thus provide an important tool to study many aspects of spermatogenesis, including the role of epigenetic mechanisms in regulating their stemness and capability for differentiating into male gametes.

Erasure of imprints in early germ cells leads to epigenetically equivalent parental chromosomes for the first and only time in the life of mammals. Transplantation of such "imprint-free" nuclei directly into oocytes leads to the development of embryos that are aberrant and die at early embryonic stages. This is presumably because without the 
appropriate epigenetic modifications, there is misexpression of genes that normally undergo imprinting. The experiment also shows that imprints cannot be acquired by imprint-free nuclei if transplanted directly to the oocyte. The initiation of DNA methylation imprints in females begins after birth, during the growth of oocytes. In male germ cells, it occurs at later fetal stages. The de novo methyltransferase Dnmt3a and its cofactor Dnmt3L play critical roles in this process (for details, see Barlow and Bartolomei 2014). Imprinting in mammals is a major barrier to parthenogenetic development. Attempts to manipulate the epigenotype of female gametes have now made it possible, however, to allow the development of mammalian embryos that are of maternal origin only (Kawahara et al. 2007).

\section{FROM THE OOCYTE TO THE EARLY EMBRYO}

We have seen in Section 1 how the cycle of germline specification involves epigenetic mechanisms, and how mature sperm and oocytes acquire very specific and different epigenetic marks during gametogenesis. Some of these differences, such as parental imprints, are maintained faithfully in the embryo after fertilization (illustrated in Fig. 7 of Barlow and Bartolomei 2014). Many others, as we will see, become dramatically reprogrammed as the embryonic genome attains totipotency. It is important to ask: To what extent do epigenetic marks inherited from the gametes play a role in the earliest differentiation events in the embryo (focusing on the right side of Fig. 2)? If you start life with one cell (the fertilized zygote) containing a complete genome that then divides, how do you ever get differentiation of gene expression and appropriate developmental programs in daughter cells? It is presumably a combination of transcription factors, epigenetic regulators, and external signaling influences that contribute to the earliest lineage decisions in mammalian development (Hemberger et al. 2009).

\subsection{Maternal Inheritance and Potential Asymmetric Distribution?}

In organisms with a large egg cell (such as Drosophila, Xenopus, or chicken), some maternally made proteins or RNAs are located asymmetrically in the egg (Fig. 3). They are then only inherited by some of the descendant cells, which subsequently develop a particular fate, whereas others that do not inherit these determinants develop differently (Huynh and St Johnston 2004). Such a strategy is possible with relatively large eggs (e.g., Drosophila), but becomes more difficult with smaller mammalian eggs. However, the developmental program may not be dictated simply by the size of the egg but, more importantly, by the necessity to generate a blastocyst in mammals that has to implant and generate a placenta to sustain the embryo. The ICM can thus be considered as developmentally equivalent to a Drosophila oocyte in the sense that it undergoes patterning in response to signals from the extraembryonic somatic tissues during early development, akin to the Drosophila syncytial cells responding to differentially distributed maternal-effect gene products. There have been some suggestions that link the symmetry of the fertilized zygote to the symmetry of the blastocyst and even the postimplantation embryo (Gardner 1997; Weber et al. 1999), but there is no unequivocal evidence for asymmetrically localized determinants of differentiation in mammalian eggs. Furthermore, mammalian embryos show a remarkable ability to "regulate" development; that is, when cells are removed or perturbed, compensatory growth or cell movements will often be able to keep the embryo developing normally (Kelly 1977). Nevertheless, there may be slightly different propensities of individual cells (blastomeres) to develop along the ICM and TE lineages as early as the four-cell stage (Fujimori et al. 2003; PiotrowskaNitsche et al. 2005), which could potentially be brought about by epigenetic factors.

\subsection{Epigenetic Events at Fertilization}

During development and differentiation, somatic cell lineages acquire very specific and specialized DNA methylation and histone modification patterns. These patterns are apparently difficult to erase or reverse when a somatic nucleus is transferred to an oocyte (elaborated in Chan et al. 2012; Hochedlinger and Jaenisch 2014). The epigenetic marks of the oocyte and the sperm are specialized too, but these are reprogrammed efficiently at fertilization so that the embryonic genome can take up its new function, namely, to become totipotent (Reik et al. 2001; Surani 2001). A number of features of the epigenetic makeup of the gametes, and the details of the epigenetic reprogramming that occurs after fertilization are now known (Fig. 2). For instance, both oocyte and sperm genomes have considerable levels of DNA methylation; as an example, the retrotransposon family, IAP, which has a copy number of approximately 1000 per mouse genome, are highly methylated both in the oocyte and sperm genome (Lane et al. 2003). In contrast, certain sequences, particularly differentially DNA-methylated regions (DMRs) in imprinted genes, are methylated only in the oocyte or sperm (see Barlow and Bartolomei 2014). Oocyte and sperm DNA methylation profiles have been determined in detail by reduced representation bisulfite sequencing or bisulfite sequencing methods (Box 1 of Li and Zhang 2014 describes 
the main DNA methylation assay techniques; Smallwood et al. 2011; Kobayashi et al. 2012; Smith et al. 2012).

The oocyte genome has high levels of histone modifications, both active ones (e.g., H3K9 acetylation and H3K4 methylation) and repressive ones (e.g., H3K9 methylation, and H3K27 methylation; Morgan et al. 2005). At this point before fertilization, the oocyte genome is transcriptionally inactive, but contains maternally inherited transcripts and proteins needed during the first few cleavage divisions, including those required for important reprogramming events (Fig. 1A). The sperm genome, in contrast, is highly specialized: The majority of the histones have been replaced during spermatogenesis by highly basic protamines, which may facilitate the packaging of DNA into the compacted sperm head (McLay and Clarke 2003). However, a minority of the sperm chromatin is organized with histones that carry modifications such as $\mathrm{H} 3 \mathrm{~K} 4$ or $\mathrm{H} 3 \mathrm{~K} 27$ methylation that are proposed to be connected with gene transcription or repression, respectively, in the early embryo (Hammoud et al. 2009; Brykczynska et al. 2010).

Shortly after fertilization, a highly regulated sequence of reprogramming events occurs in the sperm genome. Protamines are rapidly removed and replaced by histones. It is likely that being DNA replication-independent involves incorporation of the histone variant $\mathrm{H} 3.3$ by the histone chaperone HIRA (illustrated in Fig. 9 of Henikoff and Smith 2014; also see van der Heijden et al. 2005). At the same time, there is genome-wide demethylation of DNA in the male pronucleus involving single-copy and repetitive sequences, but not paternally methylated imprinted genes (Olek and Walter 1997; Oswald et al. 2000; Mayer et al. 2000; Dean et al. 2001; Santos et al. 2002; Lane et al. 2003; Smith et al. 2012).

Before DNA replication, histones in the paternal pronucleus are acetylated (H3 and $\mathrm{H} 4), \mathrm{H} 3 \mathrm{~K} 4$ methylated, and rapidly acquire $\mathrm{H} 3 \mathrm{~K} 9 \mathrm{mel}$ and $\mathrm{H} 3 \mathrm{~K} 27 \mathrm{mel}$ (Arney et al. 2002; Santos et al. 2002; Lepikhov and Walter 2004; Santos et al. 2005). H3K9me2/3 and H3K27me2/3, however, only occur subsequent to DNA replication, likely in conjunction with the incorporation of core histone H3.1 instead of H3.3 (Santos et al. 2005). By the first mitosis, most histone marks analyzed begin to be quite similar on the maternal and paternal chromosomes, at least as determined by lowresolution immunofluorescence staining (Santos et al. 2005). With the advent of chromatin immunoprecipitation-sequencing, in the years to come it should be possible to obtain higher resolution results with smaller starting material (e.g., even single cell) at a genome-wide and individual loci level.

The enzyme activities that are responsible for these early reprogramming steps are all likely to be present in the oocyte, either as protein or RNA molecules that can be rapidly translated. We already mentioned HIRA, but after DNA replication, it is CAF1 that is needed for replicationdependent incorporation of histone H3.1. The su(var) enzymes methylate $\mathrm{H} 3 \mathrm{~K} 9$, and Ezh2, together with its cofactor Eed, methylates H3K27 (Erhardt et al. 2003; Santos et al. 2005). It is likely that the dramatic DNA demethylation of the paternal genome is caused by a process of "active demethylation," which is in part now explained by oxidation of 5-methylcytosine $(5 \mathrm{mC})$ to 5-hydroxymethylcytosine $(5 \mathrm{hmC})$ and further to 5 -formylcytosine $(5 \mathrm{fC})$ and 5 carboxylcytosine $(5 \mathrm{caC})$ by the TET hydoxylase enzyme family (Branco et al. 2011; see Figs. 3 and 6 of Li and Zhang 2014). The paternal pronucleus thus rapidly loses $5 \mathrm{mC}$ and gains $5 \mathrm{hmC}$ (as well as some $5 \mathrm{fC}$ and $5 \mathrm{caC}$; Gu et al. 2011; Inoue et al. 2011; Inoue and Zhang 2011; Iqbal et al. 2011; Wossidlo et al. 2011). Indeed, TET3 protein is highly expressed in the zygote, localizes preferentially to the male pronucleus after fertilization, and is responsible for some DNA demethylation and the gain of 5hmC (Gu et al. 2011; Iqbal et al. 2011; Wossidlo et al. 2011). Base excision repair (potentially excising modified methylcytosine, illustrated in Fig. 6 of Li and Zhang 2014), the elongator complex, and DNA replication are also thought to contribute to demethylation of the paternal genome, the biological function of which remains unknown (Hajkova et al. 2010; Okada et al. 2010; Inoue and Zhang 2011; Santos et al. 2013). Why the maternal genome is not demethylated at the same time as the paternal one is a key outstanding question in this field of research. Apart from preferential localization of TET3, the maternal chromatin or pronucleus also possesses a specific protection mechanism in the form of $\mathrm{H} 3 \mathrm{~K} 9 \mathrm{me} 2$, which is apparently recognized by Stella and protects from TET3-mediated demethylation (Arney et al. 2002; Santos et al. 2002, 2005; Nakamura et al. 2007; Nakamura et al. 2012). A number of other factors, including Trim28, Kap1, and Zfp57, are also involved in "protecting" the imprints (Messerschmidt 2012).

Although the evidence mainly suggests that histone modifications are acquired rather than lost at the global level during this period, it is possible that histone arginine methylation is more dynamic. Indeed, a candidate for erasing histone arginine methylation by "deimination", Padi4, is present in the oocyte (Sarmento et al. 2004).

The main result of the rapid chromatin changes that occur at fertilization seems to be that, at the two-cell stage, the paternal genome is similar to the maternal one. This excludes DNA methylation, which differs considerably between the two genomes largely as a result of the demethylation of the sperm genome. Also, the level of analysis so far has not excluded identifying gene-specific differences in histone modifications that may be established at this stage. 


\subsection{From the Zygote to the Blastocyst}

The general theme of reprogramming, particularly of genome-wide DNA methylation patterns, continues from the two-cell stage through to the cleavage stages during preimplantation development until the embryo reaches the blastocyst stage (Monk et al. 1987; Howlett and Reik 1991; Rougier et al. 1998; Smallwood et al. 2011; Kobayashi et al. 2012; Smith et al. 2012). The precise dynamics of histone modifications are not fully described yet in the mouse, but DNA methylation is reduced stepwise with each nuclear division until the 16-cell morula stage. The reason for this is that Dnmt1, the methyltransferase that maintains methylation at $\mathrm{CpG}$ dinucleotides in a semiconservative fashion during DNA replication (see Fig. 2 of Li and Zhang 2014), is excluded from the nucleus (Carlson et al. 1992). Therefore, at each division, $50 \%$ of all genomic DNA methylation is lost. However, some sequences, such as DMRs in imprinted genes, maintain their methylation because of a certain amount of Dnmtl being retained in the nucleus, potentially targeted by the zinc finger protein Zfp57 (Hirasawa et al. 2008; Li et al. 2008). Remarkably, at the eight-cell stage, the Dnmt1 protein appears to enter the nucleus for one replication cycle. If this Dnmt1 protein is removed (by its genetic ablation in the oocyte, which provides most, if not all, of the protein during the cleavage divisions), methylation in DMRs is indeed reduced by $50 \%$, consistent with it being needed for maintenance of methylation for one round of replication only (Howell et al. 2001).

At the eight- to 16-cell stage, the outer cells of the morula flatten and become epithelial (Fig. 2); this is called compaction. This is the first outward sign of differentiation in the mammalian embryo. Over the next two to three divisions, the morula then cavitates (i.e., a cavity forms) and forms a blastocyst, distinguished by its ICM and outer TE cells. The ICM cells go on to form all lineages of the embryo and fetus, whereas the TE cells form most (but not all) lineages of the placenta (extraembryonic lineages). Shortly after this stage, another epithelial layer of cells forms on the surface of the ICM; these are PE cells, which again contribute to the placenta and the yolk sac, but not the embryo. A few genetic determinants of these very early allocation events are known: Oct4, Nanog, and Sox2 are important for the determination or maintenance of ICM cells, whereas $C d \times 2$ is required for the early maintenance of the TE cell fate (Nichols et al. 1998; Avilion et al. 2003; Chambers et al. 2003; Mitsui et al. 2003; Niwa et al. 2005), and Gata6 is important for the formation of PE cells (Lanner and Rossant 2010). The TE transcription factor Elf5 becomes rapidly methylated in the epiblast and this is important for maintaining the distinction between em- bryonic and extraembryonic cell fate (Ng et al. 2008). To what extent maternal proteins present in the oocyte or the epigenetic regulation of these genes contribute to the early cell-fate decisions in early embryos or their maintenance is currently unknown (Dean and Ferguson-Smith 2001; Torres-Padilla et al. 2010).

Major epigenetic programming events do, however, occur right at this developmental stage. The ICM cells begin to acquire DNA methylation, as judged by immunofluorescence, which is brought about by the de novo DNA methyltransferase Dnmt3b (Santos et al. 2002; Borgel et al. 2010; Smith et al. 2012). This is accompanied by increases in histone H3K9 and H3K27 methylation, transduced by G9a and Eset, and Ezh2, respectively (Fig. 2) (Erhardt et al. 2003). Although de novo methylation of DNA is not critical for the initial establishment of ICM cells, histone H3K27 methylation by Ezh2 and Eset is critical; in gene knockouts of either gene, the ICM cells do not develop properly (O'Carroll et al. 2001; Dodge et al. 2004).

In contrast to the increase in epigenetic modifications in the ICM, the TE remains largely DNA hypomethylated, as do most of the cell lineages in the later placenta (Chapman et al. 1984; Santos et al. 2002). It is thought that placental cell types need less epigenetic stability because their lifespan is much more restricted (i.e., lasting only through gestation) than that of the fetus, which continues to develop into the adult organism.

In addition to genome-wide epigenetic events during morula/blastocyst-stage development, considerable change and reprogramming occur in females on the X chromosomes. In female mouse embryos (XX), the paternally inherited $\mathrm{X}$ chromosome is always inactivated during the cleavage stages and remains so in the extraembryonic tissues (i.e., the TE and the placenta; Huynh and Lee 2003, Okamoto et al. 2005). But, in the ICM, the inactive X is reactivated and this is followed by random inactivation of one X chromosome after differentiation in the ICM-derived lineages (Mak et al. 2004; for more detail, see Figs 4 and 6 of Brockdorff and Turner 2014). Mechanistically, imprinted X inactivation (i.e., paternal X inactivation) in the preimplantation embryo involves expression of the noncoding RNA Xist from the paternal X chromosome, whose "coating" of the chromosome is thought to lead to gene silencing and the establishment of repressive epigenetic modifications (Heard 2004). Xist transcription is then down-regulated in the newly formed ICM cells, and repressive histone modifications are subsequently lost. At this stage, the chromosome becomes reactivated (Mak et al. 2004; Okamoto et al. 2004). Xist down-regulation is achieved, at least in part, by the pluripotency transcription factor network (Deuve and Avner 2011). This is followed, shortly afterward, by the initiation of random $\mathrm{X}$ inactivation in epiblast cells. 
We will see in Section 4 that ES cells are "frozen" at the stage after reactivation of the $\mathrm{X}$ chromosome such that female ES cells contain two active $\mathrm{X}$ chromosomes.

\section{FROM PLURIPOTENT STEM CELLS TO SOMATIC CELLS AND BACK TO GERM CELLS}

\subsection{Derivation of Pluripotent Stem Cells}

In Section 3.3, we learned that there are dramatic epigenetic reprogramming events in the zygote, cleavage-stage embryos, and the blastocyst, resulting in different epigenetic patterns in the ICM and TE. We now consider the genetic and epigenetic properties of early stem cells derived into culture from the blastocyst and later lineages (Fig. 1B), such as ES cells (Smith 2001), trophoblast stem (TS) cells (Rossant 2001), extraembryonic endoderm (XEN) stem cells (Kunath et al. 2005), and EG stem cells (Matsui et al. 1992).

The feature that is common to these cell types is that they can be isolated or established from intact embryos and put into culture under certain culturing conditions. Once established, they can be cultured for extended periods of time and show no signs of senescence. They can also be genetically manipulated during culture and then reintroduced into living embryos to participate in the development of the appropriate lineages.

The development of methods to generate pluripotent ES cells from ICMs was one of the most important discoveries in mammalian embryology during the 1980s. The ES cells explanted from mouse blastocysts into culture were maintained for extended culture periods, and when micro- injected back into blastocysts, they colonize all embryonic lineages (Fig. 7), thus forming chimeras (Evans and Kaufman 1981; Martin 1981). What was particularly striking was that descendants of the ES cells could colonize the germ cells and give rise to normal offspring, which were derived wholly from the ES cell genotype. This, together with the ability to genetically manipulate the ES cell genome by homologous recombination techniques leading to gene knockouts, revolutionized mouse genetics and, consequently, made the mouse the mammalian genetic model organism of choice. Considerably later, it became possible to derive ES cells from human and rat preimplantation embryos (Thomson et al. 1998; Buehr et al. 2008).

ES cells share properties with ICM/epiblast cells, but also show substantial differences, making it likely that they are a "synthetic" cell type that do not exist in the normal embryo (Smith 2001). The same is likely to apply to the other pluripotent cell lines. For example, whereas the selfrenewal of mouse ES cells requires a functional Lif/gp130/ Stat3 signaling pathway, embryos with mutations in this pathway still develop a normal ICM (Smith 2001). It is thus likely that epigenetic changes occur, and may be necessary, for the derivation and maintenance of ES cells from ICM cells. Also, outgrowths of ICM cells into culture rapidly lose expression of Oct4, and only a mouse strain from which it is relatively easy to derive ES cells, called 129Sv, retains some Oct4-expressing cells on culture. Another feature of ES cells is the epigenetic change reported in imprinted genes in both mouse and rhesus monkey; in the mouse, this can result in aberrant development of the cells when reintroduced into chimeras (Dean et al.

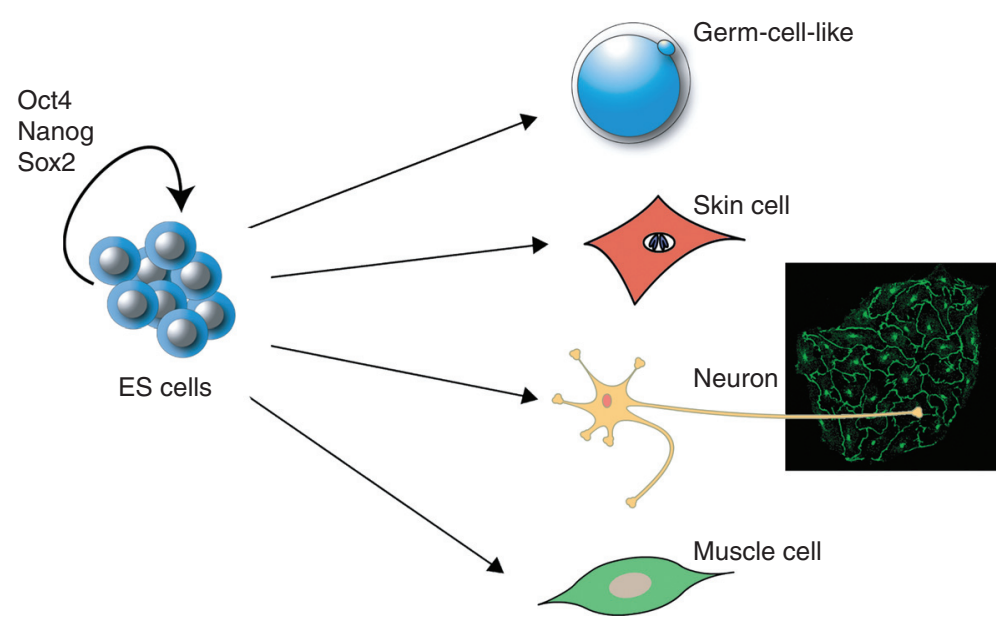

Figure 7. ES and TS cells from the blastocyst. ES cells are derived from ICM cells and can be kept in culture without differentiating. They can be genetically manipulated while in culture. ES cells can be reintroduced into blastocysts and then colonize all tissues in the embryo, including the germline, but excluding the TS cells of the placenta. TS cells can be established similarly into culture from the TE cells of the blastocyst and, when reintroduced into blastocysts, contribute to placental cell types. 
1998; Humpherys et al. 2001). One of the important determinants of ES cells in culture is the signaling system they respond to; it seems that ES cells grown in serum and leukemia inhibitory factor are epigenetically and transcriptionally somewhat heterogeneous, whereas ES cells grown in the presence of inhibitors of ERK (FGF4) and GSK3 are more homogeneous (Hayashi et al. 2008; Lanner and Rossant 2010; Leitch et al. 2010; Marks et al. 2012; Ficz et al. 2013). This may reflect the natural tendency of epiblast cells to progress from a naive state of pluripotency in the early ICM to a state in which they are primed for differentiation and thus receive increased levels of prodifferentiation FGF signals through ERK or GSK3 (for more detail on epiblast stem cells, see Hochedlinger and Jaenisch 2014).

\subsection{Epigenetic Properties of Pluripotent Cell Lines}

ES cells can be differentiated in vitro into a number of different cell lineages (Fig. 6). To what extent do epigenetic mechanisms maintain cells in an undifferentiated or differentiated state? Clearly, there are epigenomic differences between undifferentiated ES cells, differentiated ES cells, and somatic cells. Pluripotential cells are particularly characterized by the hyperdynamic plasticity of their chromatin and dynamics of DNA methylation and hydroxymethylation (Meshorer et al. 2006; Branco et al. 2011). Deletion in ES cells of Parp (poly-ADP ribosylase), which is involved in controlling the alteration of histone marks, leads to a higher frequency of transdifferentiation into TS cells, suggesting that epigenetic marks in ES cells are needed to maintain their identity (Hemberger et al. 2009). DNA methylation is also important; it epigenetically silences, for instance, the extraembryonic lineage transcription factor Elf5, whereas a lack of DNA methylation at other loci is needed to maintain ES cell fate.

The maintenance of pluripotency of ES cells depends on the transcription factors Oct4, Nanog, Sox2, and othersthe so-called pluripotency network (Young 2011). These bind alone or in combination with many gene loci in ES cells, which either need to be expressed or silenced for pluripotency to be maintained (Boyer et al. 2005; Loh et al. 2006). Differentiation of ES cells in vitro is characterized by the transcriptional silencing of pluripotency genes, which then remain repressed in somatic tissues. Epigenetic mechanisms are indeed important for their silencing; the Oct4 promoter, for example, accumulates repressive histone modifications and DNA methylation during differentiation once it has been silenced (Feldman et al. 2006). Reexpression of Oct4 in differentiated cells can, however, be triggered by a loss of DNA methylation using Dnmt1 knockout embryos (Feldman et al. 2006). This typifies the many emerging links between the pluripotency gene network and epigenetic modifiers involved in the epigenetic reprogramming of germ cells or early embryos (Gifford and Meissner 2012).

Insights into pluripotency transcription factors such as Oct4 or Nanog enabled Yamanaka and colleagues to devise their strategy for iPS (see Hochedlinger and Jaenisch 2014). The original protocol used Oct4, Sox2, Klf4, and c-myc to reprogram somatic cells to iPS cells, which are often indistinguishable from ES cells (Fig. 8) (described in Takahashi and Yamanaka 2006; Takahashi 2014). There are now many variants of the iPS protocol, including those using RNA, protein, microRNAs, or small molecule inhibitors of epigenetic modifiers. Nevertheless, the details of the reprogramming process and its kinetics, including importantly epigenetic reprogramming, remain incompletely understood (Gifford and Meissner 2012). There is the possibility that many iPS cell lines retain epigenetic memory of some kind from the tissue of origin, which needs to be taken into account when examining their differentiation potential and contemplating their use in the clinic.

ES cells and their differentiated derivatives have served as a model for the epigenetic regulation of $\mathrm{X}$ chromosome inactivation. As introduced in Section 3.3, female ICM and ES cells have a down-regulated Xist gene and two active X chromosomes. On differentiation in vitro, Xist becomes up-regulated on one of the X chromosomes, Xist RNA begins to "coat" this chromosome in cis, and silencing of genes on the $\mathrm{X}$ concomitant with the accumulation of repressive histone modifications and DNA methylation ensues (Heard 2004).

Other pluripotent cell types can be similarly established in culture, but their epigenetic properties are less well characterized than those of ES cells. It is, however, known from epigenetic studies of $\mathrm{X}$ inactivation that in female TS stem cells, there is a paternally inactivated X chromosome, as found in their originating TE cells, containing repressive histone marks (Huynh and Lee 2003). Female XEN cells also have a paternal $\mathrm{X}$ chromosome, which is inactive (Kunath et al. 2005).

Pluripotent cell lines can also be established from PGCs either during their period of migration in the embryo (E8E10.5) or once they have reached the embryonic gonads (E11.5-E13.5; Fig. 1B) (Matsui et al. 1992). PGCs, during the E8.5-11.5 stages of development, undergo extensive epigenetic reprogramming including DNA demethylation of imprinted genes and other sequences in the genome (Hajkova et al. 2002; Lee et al. 2002). Indeed, most EG cells have undergone DNA demethylation erasure of imprinted genes and other sequences and this alters their developmental potential, as shown when introduced into chimeras (Tada et al. 1998). It is not clear yet if there are epigenetic 


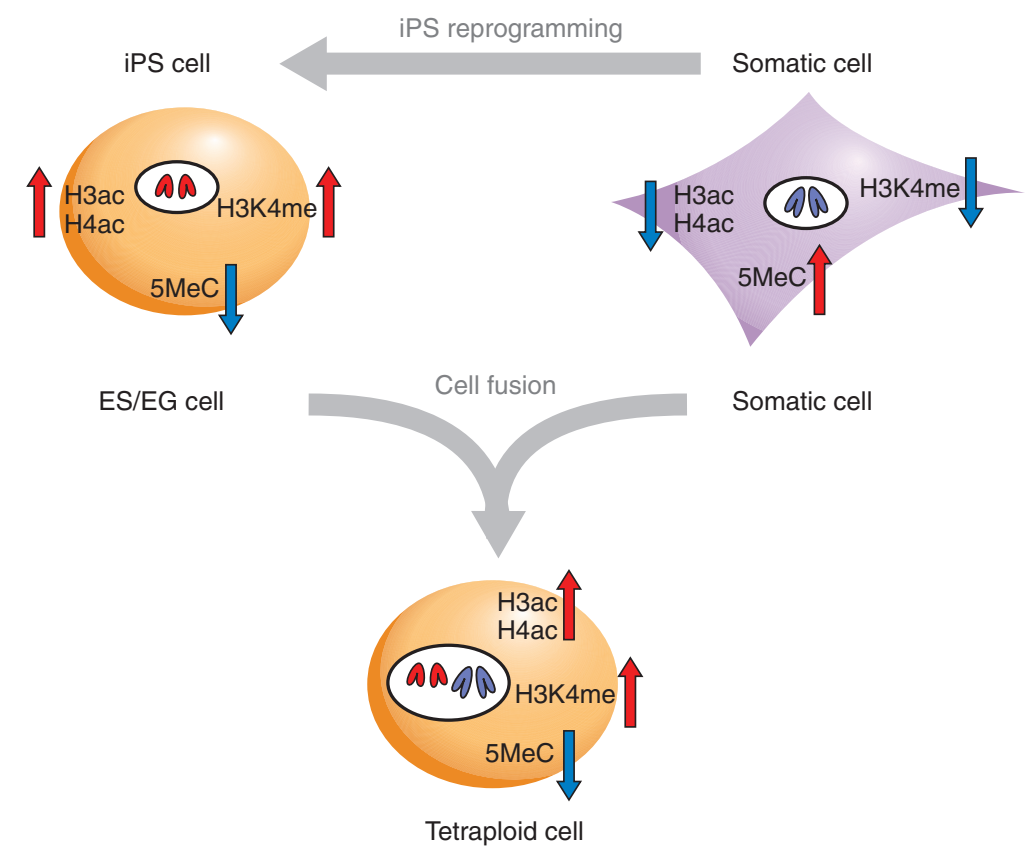

\begin{abstract}
Figure 8. Pluripotent cells have the capacity to reprogram somatic cells. ES or EG cells can be fused with somatic cells, resulting in tetraploid hybrids. This leads to epigenetic reprogramming of the somatic nucleus, with changes in, for example, 5MeC, $\mathrm{H} 3$ and $\mathrm{H} 4$ acetylation, and $\mathrm{H} 3 \mathrm{~K} 4$ methylation. The tetraploid cells resulting from this fusion or reprogramming that occurs when producing iPSCs also have a pluripotent phenotype: When injected into blastocysts, they can contribute to many different cell types in the embryo.
\end{abstract}

differences between endogenous PGCs and in vitro cultured EG cells, similar to those suspected to exist between ICM and ES cells.

\subsection{Reprogramming Capacity of Stem Cells}

The continued state of pluripotency in culture without cell senescence may well require continued epigenetic reprogramming of stem cells. That these cells indeed have reprogramming activities has been shown in fusion experiments in which EG or ES cells were fused to differentiated somatic cells (Tada et al. 1997, 2001; Cowan et al. 2005). In the tetraploid cell lines resulting from fusion, the somatic epigenotype is reprogrammed (Fig. 8). In EG-somatic cell fusions, the somatic genome loses DNA methylation at imprinted genes as well as other sequences in the genome (Tada et al. 1998). In ES-somatic cell fusions, in contrast, imprinted gene DNA methylation is retained, but the inactive $\mathrm{X}$ chromosome (in female cells) is reactivated and the promoter of the Oct4 gene becomes DNA demethylated, resulting in Oct4 reexpression (Tada et al. 2001; Cowan et al. 2005; Surani 2005). Both the AID catalyzed deamination and Tet catalyzed hydroxylation pathways for DNA demethylation (see Fig. 6 of Li and Zhang 2014) have been implicated in the reprogramming of somatic cells by ES cell fusion (Piccolo and Fisher 2013).

\section{PERSPECTIVE}

The next few years will see decisive and exciting advances in our understanding of the genetic and epigenetic factors that are critical for totipotency and pluripotency of germ and stem cells. High-throughput and sensitive methods for determining the various layers of epigenetic information of the genome are becoming widely used together with computational epigenomics developments. Factors that regulate epigenetic information, particularly those that are needed to reprogram epigenetic marks in somatic cells to ones found in pluripotent cells, have been identified. The precise temporal and cell-specific connections between the pluripotency transcription factor network, epigenetic modifiers, and signaling networks still need to be worked out and this may require systems biology-type approaches. Alongside this is the development of better methods to selectively and safely manipulate epigenetic states in vivo, ultimately for therapeutic ends.

Pluripotent stem cells present many exciting opportunities for fundamental studies as well as for their potential applications in biomedicine. In fundamental research, the uniqueness of the pluripotent state promises to provide insights into the mechanisms that regulate cell-fate decisions. The ability to differentiate into diverse cell types also provides a potential to generate replacement cells in 
the quest to repair diseased tissues. Pluripotent stem cells are also being used to develop disease models to explore how various human diseases originate from the very beginning as a result of specific mutations and epimutations (i.e., mutations caused by alterations of DNA methylation or the chromatin template, but not involving changes to the DNA sequence). Such disease models may, in turn, allow the development of new drugs to cure or even prevent diseases. Transdifferentiation technologies that directly transform one differentiated cell type into another (e.g., skin into neurons) have recently been established and this may offer new routes to therapy, avoiding the use of pluripotent cell types with the potential danger of tumor formation when cells are used for transplantation in patients (discussed further in Hochedlinger and Jaenisch 2014). There is also the prospect of reversing epigenetic effects during aging by "epigenetic rejuvenation," which is reprogramming cells to a younger and healthier cell state without going back to pluripotency (Rando and Chang 2012).

\section{ACKNOWLEDGMENTS}

The use of human pluripotent stem cells raises sensitive ethical issues that are being debated by the wider public. Appropriate ethical and regulatory frameworks are being established and continue to be refined in step with scientific progress for the use of stem cells in research and biomedical applications.

\section{REFERENCES}

* Reference is also in this collection.

* Allis CD, Jenuwein T, Reinberg D. 2014. Overview and concepts. Cold Spring Harb Perspect Biol doi: 10.1101/cshperspect.a018739.

Ancelin K, Lange UC, Hajkova P, Schneider R, Bannister AJ, Kouzarides T, Surani MA. 2006. Blimp1 associates with Prmt5 and directs histone arginine methylation in mouse germ cells. Nat Cell Biol 8: 623630.

Arney KL, Bao S, Bannister AJ, Kouzarides T, Surani MA. 2002. Histone methylation defines epigenetic asymmetry in the mouse zygote. Int $J$ Dev Biol 46: 317-320.

Avilion AA, Nicolis SK, Pevny LH, Perez L, Vivian N, Lovell-Badge R. 2003. Multipotent cell lineages in early mouse development depend on SOX2 function. Genes Dev 17: 126-140.

* Barlow DP, Bartolomei MS. 2014. Genomic imprinting in mammals. Cold Spring Harb Perspect Biol 6: a018382.

Baudat F, Buard J, Grey C, Fledel-Alon A, Ober C, Przeworski M, Coop G, de Massy B. 2010. PRDM9 is a major determinant of meiotic recombination hotspots in humans and mice. Science 327: 836-840.

Blackwell TK. 2004. Germ cells: Finding programs of mass repression. Curr Biol 14: R229-R230.

* Blewitt M, Whitelaw E. 2013. The use of mouse models to study epigenetics. Cold Spring Harb Perspect Biol 5: a017939.

Borgel J, Guibert S, Li Y, Chiba H, Schübeler D, Sasaki H, Forné T, Weber M. 2010. Targets and dynamics of promoter DNA methylation during early mouse development. Nat Genet 42: 1093-1100.
Boyer LA, Lee TI, Cole MF, Johnstone SE, Levine SS, Zucker JP, Guenther MG, Kumar RM, Murray HL, Jenner RG, et al. 2005. Core transcriptional regulatory circuitry in human embryonic stem cells. Cell 122: 947-956.

Branco MR, Ficz G, Reik W. 2011. Uncovering the role of 5-hydroxymethylcytosine in the epigenome. Nat Rev Genet 13: 7-13.

* Brockdorff N, Turner BM. 2014. Dosage compensation in mammals. Cold Spring Harb Perspect Biol doi: 10.1101/cshperspect.a019406.

Brykczynska U, Hisano M, Erkek S, Ramos L, Oakeley EJ, Roloff TC, Beisel C, Schübeler D, Stadler MB, Peters AH. 2010. Repressive and active histone methylation mark distinct promoters in human and mouse spermatozoa. Nat Struct Mol Biol 17: 679-687.

Buehr M, Meek S, Blair K, Yang J, Ure J, Silva J, McLay R, Hall J, Ying QL, Smith A. 2008. Capture of authentic embryonic stem cells from rat blastocysts. Cell 135: 1287-1298.

* Busslinger M, Tarakhovsky A. 2014. Epigenetic control of immunity. Cold Spring Harb Perspect Biol 6: a019307.

Carlson LL, Page AW, Bestor TH. 1992. Properties and localization of DNA methyltransferase in preimplantation mouse embryos: Implications for genomic imprinting. Genes Dev 6: 2536-2541.

Chambers I, Colby D, Robertson M, Nichols J, Lee S, Tweedie S, Smith A. 2003. Functional expression cloning of Nanog, a pluripotencysustaining factor in embryonic stem cells. Cell 113: 643-655.

Chan MM, Smith ZD, Egli D, Regev A, Meissner A. 2012. Mouse ooplasm confers context-specific reprogramming capacity. Nat Genet 44: 978 980.

Chapman V, Forrester L, Sanford J, Hastie N, Rossant J. 1984. Cell lineage-specific undermethylation of mouse repetitive DNA. Nature 307: 284-286.

* Cheng X. 2014. Structural and functional coordination of DNA and histone methylation. Cold Spring Harb Perspect Biol 6: a018747.

Chong S, Whitelaw E. 2004. Epigenetic germline inheritance. Curr Opin Genet Dev 14: 692-696.

Cortellino S, Xu J, Sannai M, Moore R, Caretti E, Cigliano A, Le Coz M, Devarajan K, Wessels A, Soprano D, et al. 2011. Thymine DNA glycosylase is essential for active DNA demethylation by linked deamination-base excision repair. Cell 146: 67-79.

Cowan CA, Atienza J, Melton DA, Eggan K. 2005. Nuclear reprogramming of somatic cells after fusion with human embryonic stem cells. Science 309: 1369-1373.

Dawlaty MM, Breiling A, Le T, Raddatz G, Barrasa MI, Cheng AW, Gao Q, Powell BE, Li Z, Xu M, et al. 2013. Moation. Dev Cell 24: 310-323.

Dean W, Bowden L, Aitchison A, Klose J, Moore T, Meneses JJ, Reik W, Feil R. 1998. Altered imprinted gene methylation and expression in completely ES cell-derived mouse fetuses: Association with aberrant phenotypes. Development 125: 2273-2282.

Dean W, Santos F, Stojkovic M, Zakhartchenko V, Walter J, Wolf E, Reik W. 2001. Conservation of methylation reprogramming in mammalian development: Aberrant reprogramming in cloned embryos. Proc Natl Acad Sci 98: 13734-13738.

Deshpande G, Calhoun G, Schedl P. 2004. Overlapping mechanisms function to establish transcriptional quiescence in the embryonic Drosophila germline. Development 131: 1247-1257.

de Souza FS, Gawantka V, Gomez AP, Delius H, Ang SL, Niehrs C. 1999. The zinc finger gene Xblimp1 controls anterior endomesodermal cell fate in Spemann's organizer. EMBO J 18: 6062-6072.

Deuve JL, Avner P. 2011. The coupling of X-chromosome inactivation to pluripotency. Annu Rev Cell Dev Biol 27: 611-629.

Dodge JE, Kang YK, Beppu H, Lei H, Li E. 2004. Histone H3-K9 methyltransferase ESET is essential for early development. Mol Cell Biol 24: $2478-2486$.

Erhardt S, Su IH, Schneider R, Barton S, Bannister AJ, Perez-Burgos L, Jenuwein T, Kouzarides T, Tarakhovsky A, Surani MA. 2003. Consequences of the depletion of zygotic and embryonic enhancer of zeste 2 during preimplantation mouse development. Development 130: $4235-4248$. 
Evans MJ, Kaufman MH. 1981. Establishment in culture of pluripotential cells from mouse embryos. Nature 292: 154-156.

Extavour CG, Akam M. 2003. Mechanisms of germ cell specification across the metazoans: Epigenesis and preformation. Development 130: $5869-5884$

Feldman N, Gerson A, Fang J, Li E, Zhang Y, Shinkai Y, Cedar H, Bergman Y. 2006. G9a-mediated irreversible epigenetic inactivation of Oct-3/4 during early embryogenesis. Nat Cell Biol 8: 188-194.

Feng S, Jacobsen SE, Reik W. 2010. Epigenetic reprogramming in plant and animal development. Science 330: 622-627.

Ferguson-Smith AC, Patti ME. 2011. You are what your dad ate. Cell Metab 13: 115-117.

Ficz G, Hore TA, Santos F, Lee HJ, Dean W, Arand J, Krueger F, Oxley D, Paul YL, Walter J, et al. 2013. FGF signaling inhibition in ESCs drives rapid genome-wide demethylation to the epigenetic ground state of pluripotency. Cell Stem Cell 13: 351-359.

Fujimori T, Kurotaki Y, Miyazaki J, Nabeshima Y. 2003. Analysis of cell lineage in two- and four-cell mouse embryos. Development 130: $5113-5122$.

Gardner RL. 1985. Clonal analysis of early mammalian development. Philos Trans R Soc Lond B Biol Sci 312: 163-178.

Gardner RL. 1997. The early blastocyst is bilaterally symmetrical and its axis of symmetry is aligned with the animal-vegetal axis of the zygote in the mouse. Development 124: 289-301.

Geijsen N, Horoschak M, Kim K, Gribnau J, Eggan K, Daley GQ. 2004. Derivation of embryonic germ cells and male gametes from embryonic stem cells. Nature 427: 148-154.

Gifford CA, Meissner A. 2012. Epigenetic obstacles encountered by transcription factors: Reprogramming against all odds. Curr Opin Genet Dev 22: 409-415.

Gu TP, Guo F, Yang H, Wu HP, Xu GF, Liu W, Xie ZG, Shi L, He X, Jin SG, et al. 2011. The role of Tet3 DNA dioxygenase in epigenetic reprogramming by oocytes. Nature 477: 606-610.

Guan K, Nayernia K, Maier LS, Wagner S, Dressel R, Lee JH, Nolte J, Wolf F, Li M, Engel W, et al. 2006. Pluripotency of spermatogonial stem cells from adult mouse testis. Nature 440: 1199-1203.

Guibert S, Forné T, Weber M. 2012. Global profiling of DNA methylation erasure in mouse primordial germ cells. Genome Res 22: 633-641.

Gyory I, Wu J, Fejer G, Seto E, Wright KL. 2004. PRDI-BF1 recruits the histone $\mathrm{H} 3$ methyltransferase G9a in transcriptional silencing. Nat Immunol 5: 299-308.

Hackett JA, Surani MA. 2013. Beyond DNA: Programming and inheritance of parental methylomes. Cell 172: 5427-5440.

Hackett JA, Zylicz JJ, Surani MA. 2012. Parallel mechanisms of epigenetic reprogramming in the germline. Trends Genet 28: 164-174.

Hackett JA, Sengupta R, Zylicz JJ, Murakami K, Lee C, Down TA, Surani MA. 2013. Germline DNA demethylation dynamics and imprint erasure through 5-hydroxymethylcytosine. Science 339: 448-452.

Hajkova P, Erhardt S, Lane N, Haaf T, El-Maarri O, Reik W, Walter J, Surani MA. 2002. Epigenetic reprogramming in mouse primordial germ cells. Mech Dev 117: 15-23.

Hajkova P, Ancelin K, Waldmann T, Lacoste N, Lange UC, Cesari F, Lee C, Almouzni G, Schneider R, Surani MA. 2008. Chromatin dynamics during epigenetic reprogramming in the mouse germ line. Nature 452: $877-881$.

Hajkova P, Jeffries SJ, Lee C, Miller N, Jackson SP, Surani MA. 2010. Genome-wide reprogramming in the mouse germ line entails the base excision repair pathway. Science 329: 78-82.

Hammoud SS, Nix DA, Zhang H, Purwar J, Carrell DT, Cairns BR. 2009. Distinctive chromatin in human sperm packages genes for embryo development. Nature 460: 473-478.

Hayashi K, Yoshida K, Matsui Y. 2005. A histone H3 methyltransferase controls epigenetic events required for meiotic prophase. Nature 438: $374-378$

Hayashi K, Lopes SM, Tang F, Surani MA. 2008. Dynamic equilibrium and heterogeneity of mouse pluripotent stem cells with distinct functional and epigenetic states. Cell Stem Cell 3: 391-401.
Hayashi K, Ohta H, Kurimoto K, Aramaki S, Saitou M. 2011. Reconstitution of the mouse germ cell specification pathway in culture by pluripotent stem cells. Cell 146: 519-532.

Heard E. 2004. Recent advances in X-chromosome inactivation. Curr Opin Cell Biol 16: 247-255.

Hemberger M, Dean W, Reik W. 2009. Epigenetic dynamics of stem cells and cell lineage commitment: Digging Waddington's canal. Nat Rev Mol Cell Biol 10: 526-537.

* Henikoff S, Smith MM. 2014. Histone variants and epigenetics. Cold Spring Harb Perspect Biol doi: 10.1101/cshperspect.a019364.

Hernandez-Lagunas L, Choi IF, Kaji T, Simpson P, Hershey C, Zhou Y, Zon L, Mercola M, Artinger KB. 2005. Zebrafish narrowminded disrupts the transcription factor $p r d m 1$ and is required for neural crest and sensory neuron specification. Dev Biol 278: 347-357.

Hirasawa R, Chiba H, Kaneda M, Tajima S, Li E, Jaenisch R, Sasaki H. 2008. Maternal and zygotic Dnmt1 are necessary and sufficient for the maintenance of DNA methylation imprints. Genes Dev 22: 16071616.

* Hochedlinger K, Jaenisch R. 2014. Induced pluripotency and epigenetic reprogramming. Cold Spring Harb Perspect Biol doi: 10.1101/cshper spect.a019448.

Howell CY, Bestor TH, Ding F, Latham KE, Mertineit C, Trasler JM, Chaillet JR. 2001. Genomic imprinting disrupted by a maternal effect mutation in the Dnmt1 gene. Cell 104: 829-838.

Howlett SK, Reik W. 1991. Methylation levels of maternal and paternal genomes during preimplantation development. Development 113: $119-127$.

Hubner K, Fuhrmann G, Christenson LK, Kehler J, Reinbold R, De La Fuente R, Wood J, Strauss JF 3rd, Boiani M, Scholer HR. 2003. Derivation of oocytes from mouse embryonic stem cells. Science 300: $1251-1256$.

Humpherys D, Eggan K, Akutsu H, Hochedlinger K, Rideout WM 3rd, Biniszkiewicz D, Yanagimachi R, Jaenisch R. 2001. Epigenetic instability in ES cells and cloned mice. Science 293: 95-97.

Huynh KD, Lee JT. 2003. Inheritance of a pre-inactivated paternal X chromosome in early mouse embryos. Nature 426: 857-862.

Huynh JR, St Johnston D. 2004. The origin of asymmetry: Early polarisation of the Drosophila germline cyst and oocyte. Curr Biol 14: R438-R449.

Inoue A, Zhang Y. 2011. Replication-dependent loss of 5-hydroxymethylcytosine in mouse preimplantation embryos. Science 334: 194.

Inoue A, Shen L, Dai Q, He C, Zhang Y. 2011. Generation and replication-dependent dilution of $5 \mathrm{fC}$ and $5 \mathrm{caC}$ during mouse preimplantation development. Cell Res 21: 1670-1676.

Iqbal K, Jin SG, Pfeifer GP, Szabó PE. 2011. Reprogramming of the paternal genome upon fertilization involves genome-wide oxidation of 5-methylcytosine. Proc Natl Acad Sci 108: 3642-3647.

Kagiwada S, Kurimoto K, Hirota T, Yamaji M, Saitou M. 2013. Replication-coupled passive DNA demethylation for the erasure of genome imprints in mice. $E M B O J$ 32: 340-353.

Kanatsu-Shinohara M, Inoue K, Lee J, Yoshimoto M, Ogonuki N, Miki H, Baba S, Kato T, Kazuki Y, Toyokuni S, et al. 2004. Generation of pluripotent stem cells from neonatal mouse testis. Cell 119: 10011012 .

Kawahara M, Wu Q, Takahashi N, Morita S, Yamada K, Ito M, FergusonSmith AC, Kono T. 2007. High-frequency generation of viable mice from engineered bi-maternal embryos. Nat Biotechnol 25: 1045-1050.

Kelly SJ. 1977. Studies of the developmental potential of 4- and 8-cell stage mouse blastomeres. J Exp Zool 200: 365-376.

Kimmins S, Sassone-Corsi P. 2005. Chromatin remodelling and epigenetic features of germ cells. Nature 434: 583-589.

Kobayashi H, Sakurai T, Imai M, Takahashi N, Fukuda A, Yayoi O, Sato S, Nakabayashi K, Hata K, Sotomaru Y, et al. 2012. Contribution of intragenic DNA methylation in mouse gametic DNA methylomes to establish oocyte-specific heritable marks. PLoS Genet 8: e1002440.

Kunath T, Arnaud D, Uy GD, Okamoto I, Chureau C, Yamanaka Y, Heard E, Gardner RL, Avner P, Rossant J. 2005. Imprinted X-inactivation in 
extra-embryonic endoderm cell lines from mouse blastocysts. Development 132: 1649-1661.

Kuramochi-Miyagawa S, Kimura T, Ijiri TW, Isobe T, Asada N, Fujita Y, Ikawa M, Iwai N, Okabe M, Deng W, et al. 2004. Mili, a mammalian member of piwi family gene, is essential for spermatogenesis. Development 131: 839-849.

Kurimoto K, Yabuta Y, Ohinata Y, Shigeta M, Yamanaka K, Saitou M. 2008. Complex genome-wide transcription dynamics orchestrated by Blimp1 for the specification of the germ cell lineage in mice. Genes Dev 22: 1617-1635.

Lane N, Dean W, Erhardt S, Hajkova P, Surani A, Walter J, Reik W. 2003. Resistance of IAPs to methylation reprogramming may provide a mechanism for epigenetic inheritance in the mouse. Genesis 35: $88-93$.

Lanner F, Rossant J. 2010. The role of FGF/Erk signaling in pluripotent cells. Development 137: 3351-3360.

Lawson KA, Dunn NR, Roelen BA, Zeinstra LM, Davis AM, Wright CV, Korving JP, Hogan BL. 1999. Bmp4 is required for the generation of primordial germ cells in the mouse embryo. Genes Dev 13: 424-436.

Lawson KA, Hage WJ. 1994. Clonal analysis of the origin of primordial germ cells in the mouse. Ciba Found Symp 182: 68-84.

Leatherman JL, Jongens TA. 2003. Transcriptional silencing and translational control: Key features of early germline development. Bioessays 25: $326-335$.

Lee J, Inoue K, Ono R, Ogonuki N, Kohda T, Kaneko-Ishino T, Ogura A, Ishino F. 2002. Erasing genomic imprinting memory in mouse clone embryos produced from day 11.5 primordial germ cells. Development 129: $1807-1817$.

Leitch HG, Blair K, Mansfield W, Ayetey H, Humphreys P, Nichols J, Surani MA, Smith A. 2010. Embryonic germ cells from mice and rats exhibit properties consistent with a generic pluripotent ground state. Development 137: 2279-2287.

Lepikhov K, Walter J. 2004. Differential dynamics of histone H3 methylation at positions K4 and K9 in the mouse zygote. BMC Dev Biol 4: 12.

* Li E, Zhang Y. 2014. DNA methylation in mammals. Cold Spring Harb Perspect Biol 6: a019133.

Li X, Ito M, Zhou F, Youngson N, Zuo X, Leder P, Ferguson-Smith AC. 2008. A maternal-zygotic effect gene, $Z f p 57$, maintains both maternal and paternal imprints. Dev Cell 15: 547-557.

Loh YH, Wu Q, Chew JL, Vega VB, Zhang W, Chen X, Bourque G, George J, Leong B, Liu J, et al. 2006. The Oct4 and Nanog transcription network regulates pluripotency in mouse embryonic stem cells. Nat Genet 38: 431-440.

Mak W, Nesterova TB, de Napoles M, Appanah R, Yamanaka S, Otte AP, Brockdorff N. 2004. Reactivation of the paternal X chromosome in early mouse embryos. Science 303: 666-669.

Mansour AA, Gafni O, Weinberger L, Zviran A, Ayyash M, Rais Y, Krupalnik V, Zerbib M, Amann-Zalcenstein D, Maza I, et al. 2012. The H3K27 demethylase Utx regulates somatic and germ cell epigenetic reprogramming. Nature 488: 409-413.

Marks H, Kalkan T, Menafra R, Denissov S, Jones K, Hofemeister H, Nichols J, Kranz A, Stewart AF, Smith A, et al. 2012. The transcriptional and epigenomic foundations of ground state pluripotency. Cell 149: 590-604.

Martin GR. 1981. Isolation of a pluripotent cell line from early mouse embryos cultured in medium conditioned by teratocarcinoma stem cells. Proc Natl Acad Sci 78: 7634-7638.

Martinho RG, Kunwar PS, Casanova J, Lehmann R. 2004. A noncoding RNA is required for the repression of RNApolII-dependent transcription in primordial germ cells. Curr Biol 14: 159-165.

Matsui Y, Zsebo K, Hogan BL. 1992. Derivation of pluripotential embryonic stem cells from murine primordial germ cells in culture. Cell 70: $841-847$.

Mayer W, Niveleau A, Walter J, Fundele R, Haaf T. 2000. Demethylation of the zygotic paternal genome. Nature 403: 501-502.
McLaren A. 2003. Primordial germ cells in the mouse. Dev Biol 262: $1-15$.

McLaren A, Lawson KA. 2005. How is the mouse germ-cell lineage established? Differentiation 73: 435-437.

McLay DW, Clarke HJ. 2003. Remodelling the paternal chromatin at fertilization in mammals. Reproduction 125: 625-633.

Meshorer E, Yellajoshula D, George E, Scambler PJ, Brown DT, Misteli T. 2006. Hyperdynamic plasticity of chromatin proteins in pluripotent embryonic stem cells. Dev Cell 10: 105-116.

Messerschmidt DM. 2012. Should I stay or should I go: Protection and maintenance of DNA methylation at imprinted genes. Epigenetics 7: 969-975.

Mitsui K, Tokuzawa Y, Itoh H, Segawa K, Murakami M, Takahashi K, Maruyama M, Maeda M, Yamanaka S. 2003. The homeoprotein Nanog is required for maintenance of pluripotency in mouse epiblast and ES cells. Cell 113: 631-642.

Monk M, Boubelik M, Lehnert S. 1987. Temporal and regional changes in DNA methylation in the embryonic, extraembryonic and germ cell lineages during mouse embryo development. Development 99: 371382.

Morgan HD, Santos F, Green K, Dean W, Reik W. 2005. Epigenetic reprogramming in mammals. Hum Mol Genet 14: R47-R58.

Nakamura T, Arai Y, Umehara H, Masuhara M, Kimura T, Taniguchi H, Sekimoto T, Ikawa M, Yoneda Y, Okabe M, et al. 2007. PGC7/Stella protects against DNA demethylation in early embryogenesis. Nat Cell Biol 9: 64-71.

Nakamura T, Liu YJ, Nakashima H, Umehara H, Inoue K, Matoba S, Tachibana M, Ogura A, Shinkai Y, Nakano T. 2012. PGC7 binds histone $\mathrm{H} 3 \mathrm{~K} 9 \mathrm{me} 2$ to protect against conversion of $5 \mathrm{mC}$ to $5 \mathrm{hmC}$ in early embryos. Nature 486: 415-419.

Ng RK, Dean W, Dawson C, Lucifero D, Madeja Z, Reik W, Hemberger M. 2008. Epigenetic restriction of embryonic cell lineage fate by methylation of Elf5. Nat Cell Biol 10: 1280-1290.

Nichols J, Zevnik B, Anastassiadis K, Niwa H, Klewe-Nebenius D, Chambers I, Scholer H, Smith A. 1998. Formation of pluripotent stem cells in the mammalian embryo depends on the POU transcription factor Oct4. Cell 95: 379-391.

Niwa H, Toyooka Y, Shimosato D, Strumpf D, Takahashi K, Yagi R, Rossant J. 2005. Interaction between Oct $3 / 4$ and Cdx2 determines trophectoderm differentiation. Cell 123: 917-929.

O'Carroll D, Erhardt S, Pagani M, Barton SC, Surani MA, Jenuwein T. 2001. The Polycomb-group gene Ezh2 is required for early mouse development. Mol Cell Biol 21: 4330-4336.

Ohinata Y, Payer B, O'Carroll D, Ancelin K, Ono Y, Sano M, Barton SC, Obukhanych T, Nussenzweig M, Tarakhovsky A, et al. 2005. Blimp1 is a critical determinant of the germ cell lineage in mice. Nature 436: $207-213$

Ohinata Y, Ohta H, Shigeta M, Yamanaka K, Wakayama T, Saitou M. 2009. A signaling principle for the specification of the germ cell lineage in mice. Cell 137: 571-584.

Okada Y, Yamagata K, Hong K, Wakayama T, Zhang Y. 2010. A role for the elongator complex in zygotic paternal genome demethylation. Nature 463: $554-558$.

Okamoto I, Otte AP, Allis CD, Reinberg D, Heard E. 2004. Epigenetic dynamics of imprinted $\mathrm{X}$ inactivation during early mouse development. Science 303: 644-649.

Okamoto I, Arnaud D, Le Baccon P, Otte AP, Disteche CM, Avner P, Heard E. 2005. Evidence for de novo imprinted X-chromosome inactivation independent of meiotic inactivation in mice. Nature 438: 369-373.

Olek A, Walter J. 1997. The pre-implantation ontogeny of the H19 methylation imprint. Nat Genet 17: 275-276.

Oswald J, Engemann S, Lane N, Mayer W, Olek A, Fundele R, Dean W, Reik W, Walter J. 2000. Active demethylation of the paternal genome in the mouse zygote. Curr Biol 10: 475-478.

Parvanov ED, Petkov PM, Paigen K. 2010. Prdm9 controls activation of mammalian recombination hotspots. Science 327: 835. 
Peters AH, O'Carroll D, Scherthan H, Mechtler K, Sauer S, Schofer C, Weipoltshammer K, Pagani M, Lachner M, Kohlmaier A, et al. 2001. Loss of the Suv39h histone methyltransferases impairs mammalian heterochromatin and genome stability. Cell 107: 323-337.

Piccolo FM, Fisher AG. 2013. Getting rid of DNA methylation. Trends Cell Biol doi: 10.1016/j.tcb.2013.09.001.

Piotrowska-Nitsche K, Perea-Gomez A, Haraguchi S, Zernicka-Goetz M. 2005. Four-cell stage mouse blastomeres have different developmental properties. Development 132: 479-490.

Popp C, Dean W, Feng S, Cokus SJ, Andrews S, Pellegrini M, Jacobsen SE, Reik W. 2010. Genome-wide erasure of DNA methylation in mouse primordial germ cells is affected by AID deficiency. Nature 463: 11011105.

Rando TA, Chang HY. 2012. Aging, rejuvenation and epigenetic reprogramming: Resetting the aging clock. Cell 148: 46-57.

Reik W, Dean W, Walter J. 2001. Epigenetic reprogramming in mammalian development. Science 293: 1089-1093.

Ren B, Chee KJ, Kim TH, Maniatis T. 1999. PRDI-BF1/Blimp-1 repression is mediated by corepressors of the Groucho family of proteins. Genes Dev 13: 125-137.

Resnick JL, Bixler LS, Cheng L, Donovan PJ. 1992. Long-term proliferation of mouse primordial germ cells in culture. Nature 359: 550-551.

Rossant J. 2001. Stem cells from the mammalian blastocyst. Stem Cells 19: $477-482$.

Rougier N, Bourc'his D, Gomes DM, Niveleau A, Plachot M, Paldi A, Viegas-Pequignot E. 1998. Chromosome methylation patterns during mammalian preimplantation development. Genes Dev 12: 21082113.

Roy S, Ng T. 2004. Blimp-1 specifies neural crest and sensory neuron progenitors in the zebrafish embryo. Curr Biol 14: 1772-1777.

Saitou M, Barton SC, Surani MA. 2002. A molecular programme for the specification of germ cell fate in mice. Nature 418: 293-300.

Saitou M, Payer B, Lange UC, Erhardt S, Barton SC, Surani MA. 2003. Specification of germ cell fate in mice. Philos Trans R Soc Lond B Biol Sci 358: $1363-1370$.

Saitou M, Kagiwada S, Kurimoto K. 2012. Epigenetic reprogramming in mouse pre-implantation development and primordial germ cells. Development 139: 15-31.

Santos F, Hendrich B, Reik W, Dean W. 2002. Dynamic reprogramming of DNA methylation in the early mouse embryo. Dev Biol 241: 172-182.

Santos F, Peters AH, Otte AP, Reik W, Dean W. 2005. Dynamic chromatin modifications characterise the first cell cycle in mouse embryos. Dev Biol 280: 225-236.

Santos F, Peat J, Burgess H, Rada C, Reik W, Dean W. 2013. Active demethylation in mouse zygotes involves cytosine deamination and base excision repair. Epigenetics Chromatin 6: 39.

Sarmento OF, Digilio LC, Wang Y, Perlin J, Herr JC, Allis CD, Coonrod SA. 2004. Dynamic alterations of specific histone modifications during early murine development. J Cell Sci 117: 4449-4459.

Schaner CE, Deshpande G, Schedl PD, Kelly WG. 2003. A conserved chromatin architecture marks and maintains the restricted germ cell lineage in worms and flies. Dev Cell 5: 747-757.

Sciammas R, Davis MM. 2004. Modular nature of Blimp-1 in the regulation of gene expression during B cell maturation. J Immunol 172: 5427-5440.

Seisenberger S, Andrews S, Krueger F, Arand J, Walter J, Santos F, Popp C, Thienpont B, Dean W, Reik W. 2012. The dynamics of genome-wide DNA methylation reprogramming in mouse primordial gene cells. Mol Cell 48: 849-862.

Seki Y, Yamaji M, Yabuta Y, Sano M, Shigeta M, Matsui Y, Saga Y, Tachibana M, Seki Y, Hayashi K, Itoh K, Mizugaki M, Saitou M, Matsui Y. 2005. Extensive and orderly reprogramming of genome-wide chromatin modifications associated with specification and early development of germ cells in mice. Dev Biol 278: 440-458.

Seki Y, Yamaji M, Yabuta Y, Sano M, Shigeta M, Matsui Y, Saga Y, Tachibana M, Shinkai Y, Saitou M. 2007. Cellular dynamics associated with the genome-wide epigenetic reprogramming in migrating primordial germ cells in mice. Development 13: 2627-2638.

Seydoux G, Dunn MA. 1997. Transcriptionally repressed germ cells lack a subpopulation of phosphorylated RNA polymerase II in early embryos of Caenorhabditis elegans and Drosophila melanogaster. Development 124: 2191-2201.

Seydoux G, Strome S. 1999. Launching the germline in Caenorhabditis elegans: Regulation of gene expression in early germ cells. Development 126: $3275-3283$.

Siomi MC, Sato K, Pezic D, Aravin AA. 2011. PIWI-interacting small RNAs: The vanguard of genome defence. Nat Rev Mol Cell Biol 12: $246-258$

Smallwood SA, Tomizawa S, Krueger F, Ruf N, Carli N, Segonds-Pichon A, Sato S, Hata K, Andrews SR, Kelsey G. 2011. Dynamic CpG island methylation landscape in oocytes and preimplantation embryos. Nat Genet 43: 811-814.

Smith AG. 2001. Embryo-derived stem cells: Of mice and men. Annu Rev Cell Dev Biol 17: 435-462.

Smith ZD, Chan MM, Mikkelsen TS, Gu H, Gnirke A, Regev A, Meissner A. 2012. A unique regulatory phase of DNA methylation in the early mammalian embryo. Nature 484: 339-344.

Surani MA. 2001. Reprogramming of genome function through epigenetic inheritance. Nature 414: 122-128.

Surani MA, Ancelin K, Hajkova P, Lange UC, Payer B, Western P, Saitou M. 2004. Mechanism of mouse germ cell specification: A genetic program regulating epigenetic reprogramming. Cold Spring Harb Symp Quant Biol 69: 1-9.

Surani MA. 2005. Nuclear reprogramming by human embryonic stem cells. Cell 122: 653-654.

Tada M, Tada T, Lefebvre L, Barton SC, Surani MA. 1997. Embryonic germ cells induce epigenetic reprogramming of somatic nucleus in hybrid cells. EMBO J 16: 6510-6520.

Tada T, Tada M, Hilton K, Barton SC, Sado T, Takagi N, Surani MA. 1998. Epigenotype switching of imprintable loci in embryonic germ cells. Dev Genes Evol 207: 551-561.

Tada M, Takahama Y, Abe K, Nakatsuji N, Tada T. 2001. Nuclear reprogramming of somatic cells by in vitro hybridization with ES cells. Curr Biol 11: 1553-1558.

* Takahashi K. 2014. Cellular reprogramming. Cold Spring Harb Perspect Biol 6: a018606.

Takahashi K, Yamanaka S. 2006. Induction of pluripotent stem cells from mouse embryonic and adult fibroblast cultures by defined factors. Cell 126: $663-676$.

Thomson JA, Itskovitz-Eldor J, Shapiro SS, Waknitz MA, Swiergiel JJ, Marshall VS, Jones JM. 1998. Embryonic stem cell lines derived from human blastocysts. Science 282: 1145-1147.

Torres-Padilla ME, Parfitt DE, Kouzarides T, Zernicka-Goetz M. 2010. Histone arginine methylation regulates pluripotency in the early mouse embryo. Nature 445: 214-218.

Toyooka Y, Tsunekawa N, Akasu R, Noce T. 2003. Embryonic stem cells can form germ cells in vitro. Proc Natl Acad Sci 100: 1145711462.

Turner CA Jr, Mack DH, Davis MM. 1994. Blimp-1, a novel zinc fingercontaining protein that can drive the maturation of B lymphocytes into immunoglobulin-secreting cells. Cell 77: 297-306.

van der Heijden GW, Dieker JW, Derijck AA, Muller S, Berden JH, Braat DD, van der Vlag J, de Boer P. 2005. Asymmetry in histone H3 variants and lysine methylation between paternal and maternal chromatin of the early mouse zygote. Mech Dev 122: 1008-1022.

Vincent SD, Dunn NR, Sciammas R, Shapiro-Shalef M, Davis MM, Calame K, Bikoff EK, Robertson EJ. 2005. The zinc finger transcriptional repressor Blimp1/Prdm1 is dispensable for early axis formation but is required for specification of primordial germ cells in the mouse. Development 132: 1315-1325.

Vincent JJ, Li Z, Lee SA, Liu X, Etter MO, Diaz-Perez SV, Taylor SK, Gkountela S, Lindgren AG, Clark AT. 2011. Single cell analysis facilities 
staging of Blimp1-dependent primordial germ cells derived from mouse embryonic stem cells. PLoS ONE 6: e28960.

Vincent JJ, Huang Y, Chen PY, Feng S, Calvopiña JH, Nee K, Lee SA, Le T, Yoon AJ, Faull K, et al. 2013. Stage-specific roles for Tet1 and Tet2 in DNA demethylation in primordial germ cells. Cell Stem Cell 12: $470-478$.

Waddington C. 1956. Principles of embryology. Allen and Unwin, London. Weber RJ, Pedersen RA, Wianny F, Evans MJ, Zernicka-Goetz M. 1999. Polarity of the mouse embryo is anticipated before implantation. Development 126: 5591-5598.

Wossidlo M, Nakamura T, Lepikhov K, Marques CJ, Zakhartchenko V, Boiani M, Arand J, Nakano T, Reik W, Walter J. 2011. 5-Hydroxymethylcytosine in the mammalian zygote is linked with epigenetic reprogramming. Nat Commun 2: 241.
Yamaguchi S, Kimura H, Tada M, Nakatsuji N, Tada T. 2005. Nanog expression in mouse germ cell development. Gene Expr Patterns 5: 639-646. Yamaguchi S, Hong K, Liu R, Inoue A, Shen L, Zhang K, Zhang Y. 2013. Dynamics of 5-methylcytosine and 5-hydroxymethylcytosine during germ cell reprogramming. Cell Res 23: 329-339.

Yamaji M, Seki Y, Kurimoto K, Yabuta Y, Yuasa M, Shigeta M, Yamanaka K, Ohinata Y, Saitou M. 2008. Critical function of Prdm14 for the establishment of the germ cell lineage in mice. Nat Genet 40: 10161022.

Young RA. 2011. Control of the embryonic stem cell state. Cell 144: $940-$ 954.

Zhang F, Barboric M, Blackwell TK, Peterlin BM. 2003. A model of repression: CTD analogs and PIE-1 inhibit transcriptional elongation by P-TEFb. Genes Dev 17: 748-758. 


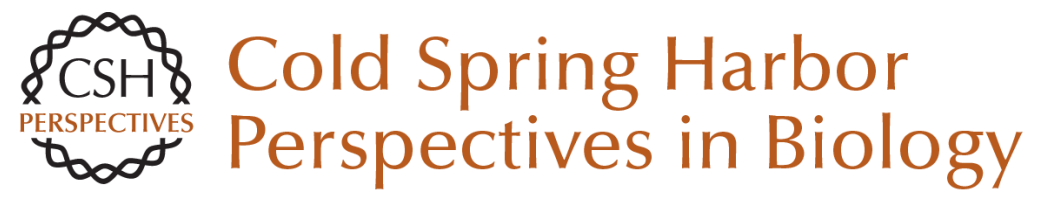

\section{Germline and Pluripotent Stem Cells}

Wolf Reik and M. Azim Surani

Cold Spring Harb Perspect Biol 2015; doi: 10.1101/cshperspect.a019422

Subject Collection Epigenetics

Metabolic Signaling to Chromatin Shelley L. Berger and Paolo Sassone-Corsi

Histone and DNA Modifications as Regulators of Neuronal Development and Function Stavros Lomvardas and Tom Maniatis

Histone Modifications and Cancer James E. Audia and Robert M. Campbell

Epigenetics and Human Disease Huda Y. Zoghbi and Arthur L. Beaudet

Induced Pluripotency and Epigenetic Reprogramming Konrad Hochedlinger and Rudolf Jaenisch

Long-Range Chromatin Interactions Job Dekker and Tom Misteli

RNAi and Heterochromatin Assembly Robert Martienssen and Danesh Moazed

Dosage Compensation in Drosophila John C. Lucchesi and Mitzi I. Kuroda
Epigenetic Determinants of Cancer Stephen B. Baylin and Peter A. Jones

Maintenance of Epigenetic Information Geneviève Almouzni and Howard Cedar

A Structural Perspective on Readout of Epigenetic Histone and DNA Methylation Marks Dinshaw J. Patel

The Necessity of Chromatin: A View in

Perspective Vincenzo Pirrotta

Germline and Pluripotent Stem Cells Wolf Reik and M. Azim Surani

Comprehensive Catalog of Currently Documented Histone Modifications Yingming Zhao and Benjamin A. Garcia

Epigenetic Regulation of Chromatin States in Schizosaccharomyces pombe Robin C. Allshire and Karl Ekwall

Histone Variants and Epigenetics Steven Henikoff and M. Mitchell Smith

For additional articles in this collection, see http://cshperspectives.cshlp.org/cgi/collection/

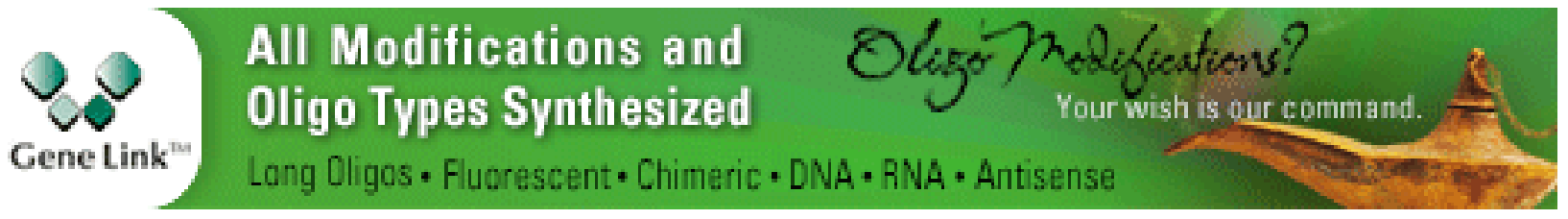

Copyright (C 2015 Cold Spring Harbor Laboratory Press; all rights reserved 
For additional articles in this collection, see http://cshperspectives.cshlp.org/cgi/collection/

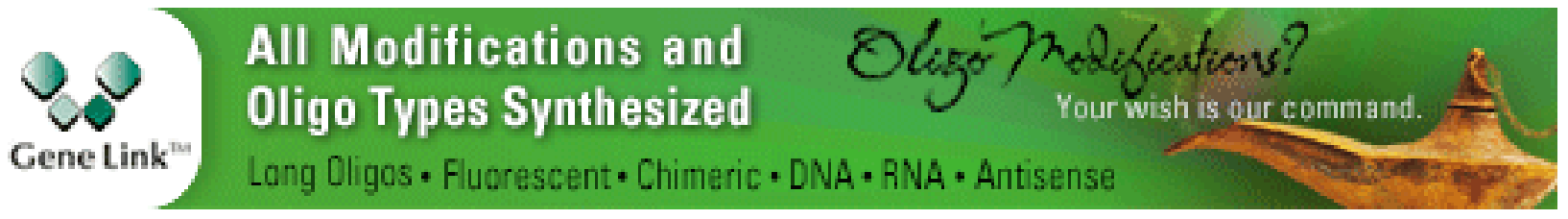

Copyright @ 2015 Cold Spring Harbor Laboratory Press; all rights reserved 